OPEN ACCESS

Edited by:

Christophe Dupraz,

Stockholm University, Sweden

Reviewed by:

Virginia Helena Albarracín,

Center for Electron Microscopy

(CIME), Argentina

John Senko,

University of Akron, United States

*Correspondence:

Estela C. Mlewski

cmlewski@gmail.com

Emmanuelle Gérard

emgerard@ipgp.fr

†These authors have contributed equally to this work

Specialty section:

This article was submitted to

Aquatic Microbiology,

a section of the journal

Frontiers in Microbiology

Received: 30 January 2018 Accepted: 27 April 2018

Published: 22 May 2018

Citation:

Mlewski EC, Pisapia C, Gomez F.

Lecourt L, Soto Rueda E,

Benzerara K, Ménez B, Borensztajn S, Jamme $F$, Réfrégiers $M$ and Gérard $E$

(2018) Characterization of Pustular

Mats and Related Rivularia-Rich Laminations in Oncoids From the

Laguna Negra Lake (Argentina).

Front. Microbiol. 9:996.

doi: 10.3389/fmicb.2018.00996

\section{Characterization of Pustular Mats and Related Rivularia-Rich Laminations in Oncoids From the Laguna Negra Lake (Argentina)}

\author{
Estela C. Mlewski ${ }^{1 * t}$, Céline Pisapia ${ }^{2,3 t}$, Fernando Gomez ${ }^{1}$, Lena Lecourt', \\ Eliana Soto Rueda ${ }^{1}$, Karim Benzerara ${ }^{4}$, Bénédicte Ménez ${ }^{2}$, Stephan Borensztajn ${ }^{2}$, \\ Frédéric Jamme ${ }^{3}$, Matthieu Réfrégiers ${ }^{3}$ and Emmanuelle Gérard ${ }^{2 *}$ \\ ${ }^{1}$ Centro de Investigaciones en Ciencias de la Tierra (CICTERRA), Cordoba, Argentina, ${ }^{2}$ Institut de Physique du Globe de \\ Paris, Sorbonne Paris Cité, Centre National de la Recherche Scientifique, Université Paris Diderot, Paris, France, \\ ${ }^{3}$ Synchrotron SOLEIL, DISCO Beamline, Saint Aubin, France, ${ }^{4}$ Institut de Minéralogie, de Physique des Matériaux et de \\ Cosmochimie, UMR Centre National de la Recherche Scientifique 7590, Sorbonne Université, Muséum National d'Histoire \\ Naturelle, IRD UMR 206, Paris, France
}

Stromatolites are organo-sedimentary structures that represent some of the oldest records of the early biosphere on Earth. Cyanobacteria are considered as a main component of the microbial mats that are supposed to produce stromatolite-like structures. Understanding the role of cyanobacteria and associated microorganisms on the mineralization processes is critical to better understand what can be preserved in the laminated structure of stromatolites. Laguna Negra (Catamarca, Argentina), a high-altitude hypersaline lake where stromatolites are currently formed, is considered as an analog environment of early Earth. This study aimed at characterizing carbonate precipitation within microbial mats and associated oncoids in Laguna Negra. In particular, we focused on carbonated black pustular mats. By combining Confocal Laser Scanning Microscopy, Scanning Electron Microscopy, Laser Microdissection and Whole Genome Amplification, Cloning and Sanger sequencing, and Focused lon Beam milling for Transmission Electron Microscopy, we showed that carbonate precipitation did not directly initiate on the sheaths of cyanobacterial Rivularia, which dominate in the mat. It occurred via organo-mineralization processes within a large EPS matrix excreted by the diverse microbial consortium associated with Rivularia where diatoms and anoxygenic phototrophic bacteria were particularly abundant. By structuring a large microbial consortium, Rivularia should then favor the formation of organic-rich laminations of carbonates that can be preserved in stromatolites. By using Fourier Transform Infrared spectroscopy and Synchrotron-based deep UV fluorescence imaging, we compared laminations rich in structures resembling Rivularia to putatively chemically-precipitated laminations in oncoids associated with the mats. We showed that they presented a different mineralogy jointly with a higher content in organic remnants, hence providing some criteria of biogenicity to be searched for in the fossil record.

Keywords: Rivularia, carbonate precipitation, oncoids, Andean lakes, pustular mats 


\section{INTRODUCTION}

Microbialites record microbial activities and sedimentary processes under a lithified form (Walter et al., 1972; Burne and Moore, 1987). Stromatolites are laminated microbialites probably produced by lithification of microbial mats (Knoll, 2003; Bosak et al., 2007). Yet, comparable stromatolite-like products can form abiotically, casting doubts on the biological origin of some fossil stromatolites (Buick et al., 1981; Grotzinger and Knoll, 1999). Stromatolites are pervasive in the Precambrian fossil record. They can be traced back to the early Archean, 3.43 billion years (Awramik and Sprinkle, 1999; Allwood et al., 2006) and even 3.7 billion years ago (Nutman et al., 2016). Understanding the mechanisms of stromatolite formation is thus mandatory for the quest of the oldest traces of life on Earth and for documenting the early Earth environment. Notably, it is important to decipher the role played by microbial activity on the lithification processes. Microbial metabolisms known to favor carbonate precipitation (by reaching supersaturation with respect to carbonates through increased alkalinity) include oxygenic and anoxygenic photosynthesis, ureolysis, ammonification, denitrification, sulfate and iron reduction, anaerobic sulfide oxidation, or methane oxidation (Dupraz and Visscher, 2005; Dupraz et al., 2009; Zhu and Dittrich, 2016). In addition, microbial exopolymeric substances (EPS), consisting of a mixture of carbohydrates, proteins and nucleic acids, may promote or inhibit solid carbonate formation (e.g., Benzerara et al., 2006), possibly depending on their divalent-cation binding capacity (Braissant et al., 2007; Glunk et al., 2011). Among other phyla, cyanobacteria are important producers of EPS in microbialites (e.g., Foster et al., 2009) and it has long been suggested that the formation of some ancient stromatolites was mediated by oxygenic photosynthesis performed by cyanobacteria (Arp et al., 2001; Aloisi et al., 2006; Altermann et al., 2006; Riding, 2006). However, several studies have indicated that primary production in stromatolites could be partly performed by other organisms such as diatoms, anoxygenic phototrophs and/or non-phototrophic carbon fixers (Braissant et al., 2003; Bosak et al., 2007; Meister, 2013; Saghaï et al., 2015). The study of modern stromatolites may help to better understand the impact of these different metabolic processes on microbialite formation, some of which may have also played a role in the formation of ancient stromatolites. Furthermore, understanding stromatolites is attractive for petroleum geologists with the recent discovery of oil reservoir associated with stromatolites in the South Oman Salt Basin and the "pre-salt" deposits offshore of Brazil (Bosence et al., 2015). Overall, there is a need to document in a broader range of environments the type of microorganisms which contribute to carbonate precipitation in modern microbialites. Modern microbialites and stromatolites currently develop in restrictive, sometimes extreme environments such as the hypersaline Shark Bay in Australia (Logan, 1961), hot springs (Berelson et al., 2011), alkaline lakes (e.g., Kempe et al., 1991; Chagas et al., 2016) and also high-altitude lakes like Socompa, Brava, and Tebenquiche lakes in the Andes (Farías et al., 2013, 2014; Fernandez et al., 2015).
The Laguna Negra is a high-altitude hypersaline lake in Catamarca, Argentina where extreme environmental conditions (i.e., high UV-radiation and extreme temperature, salinity, and water activity) restrict eukaryotic life. Lithification is controlled by environmental processes (Gomez et al., 2014) along with microbial mats where diatoms and anoxygenic phototrophic bacteria are abundant (Gomez et al., 2018). This latter work focused on the texture, mineralogy and stable isotope geochemistry of subfossil oncoids and related microbialites from the Laguna Negra stromatolite belt. This belt mostly consists of carbonated laminar crusts, stromatolites and oncoids. Different types of carbonate laminations were identified within the oncoids based on their texture (e.g., micritic, sparry, botryoidal, tufted filament-rich palisade fabrics). These different laminations were partly associated with different microbial communities (i.e., stratified pink colored, greenish and black pustular mats; Gomez et al., 2018). Interestingly, laminations with calcified Rivularialike cyanobacterial filaments showing tufted palisade fabrics were found alternating with micritic and botryoidal laminations. Consequently, potential changes in the microbial community could possibly be recorded within the oncoids as different types of laminations.

The main objectives of this study were (i) to investigate at Laguna Negra the potential role of a microbial consortium forming the black pustular mat (BP) on the initiation of carbonate precipitation and lamination formation and (ii) to identify biogenicity criteria for the corresponding laminations in subfossil oncoids. By jointly using Confocal Laser Scanning Microscopy (CLSM), Scanning and Transmission Electron Microscopy (SEM/TEM) associated with Energy Dispersive Xray Spectrometry (EDXS) and Focused Ion Beam (FIB) milling, as well as phylogenetic analyses on the bulk BP mat and on laser microdissected mat cells, we highlighted the presence of an interesting microbial consortium associated with Rivularia filaments that triggers carbonate precipitation in the BP mats. In parallel, we determined the composition of the corresponding fossil laminations on oncoids associated with BP mats in order to identify potential biomarkers. By using Fourier Transform Infrared microspectroscopy (FTIR), powder X-Ray Diffraction (XRD) and Synchrotron-based deep UV fluorescence imaging (S-DUV), we clearly highlighted that these laminations present a different pattern compared to putatively chemically-formed laminations, hence providing for laminations some criteria of biogenicity to be searched for in the fossil record.

\section{MATERIALS AND METHODS}

\section{Sample Collection and Fixation}

The Laguna Negra is a high altitude lake $(4,100 \mathrm{~m}$ above sea level) located in the Puna region of the Catamarca Province, Argentina (Figure 1A). At the southeastern edge of the Laguna Negra, a stromatolite belt of around $0.3 \mathrm{~km}^{2}$ is observed. This belt mostly consists of oncoids and associated microbial mats with morphological and textural differences described in Gomez et al. (2014) (Figures 1B-D). Samples analyzed in this study were collected during two field trips in 2013 (autumn) and in 2015 (spring). We focused on particular black pustular mats 


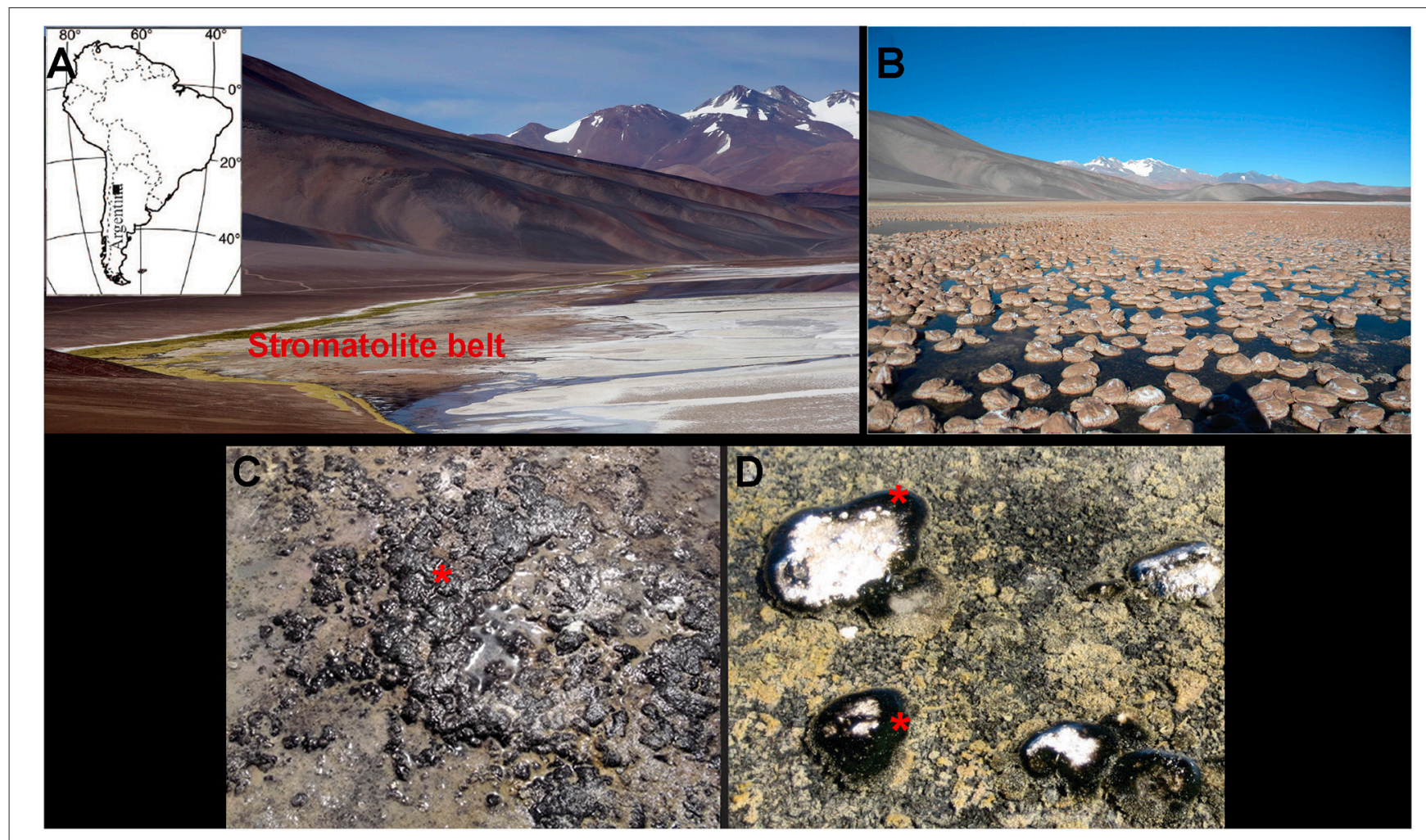

FIGURE 1 | (A) Location map of the Laguna Negra (LN) lake in the Catamarca province, Argentina (indicated by a black square) along with a panoramic view of the lake shore and the stromatolite belt. (B) Close view of the subspherical oncoids that compose the stromatolite belt. (C) Emerged black pustular (BP) mat and (D) BP mat covering the periphery of partly emerged oncoids (red asterisks).

usually found in the shallow shore of the lake (Figure 1C), and sometimes covering the periphery of partly emerged oncoids (Figure 1D) where the samples were taken. Mats were sampled with sterile instruments and gloves. Samples for DNA analyses were stored in the dark at $-20^{\circ} \mathrm{C}$ until used, or in RNAlater ${ }^{\circledR}$ (Ambion, Inc.). Samples for SEM-EDXS were fixed in the laboratory with a $2 \%$ glutaraldehyde solution and stored in the dark at $4^{\circ} \mathrm{C}$ for $2 \mathrm{~h}$. After fixation, samples were washed and progressively dehydrated in a gradual series of ethanol and water baths at increasing ethanol concentrations (i.e., 10, 30, 50, 70, and $100 \%$ ), prior to air drying or critical point drying (CPD7501, Quorum Technologies). Samples for CLSM were fixed in $4 \%$ paraformaldehyde solution directly in the field at $4^{\circ} \mathrm{C}$, then washed in phosphate buffered saline (PBS) once back in the laboratory and stored in (1/1) ethanol/PBS solution at $-20^{\circ} \mathrm{C}$ until use. Oncoids and microbialites were also collected and stored at $4{ }^{\circ} \mathrm{C}$ without any chemical fixation.

\section{Calcein Staining and Resin Embedding of BP Microbialites}

Calcein (2,4-bis-[N, $\mathrm{N}^{\prime}$-di(carbomethyl)-aminomethyl]fluorescein) produces a stable fluorescent complex in the presence of calcium, strontium, barium, and magnesium ions (Diehl and Ellingboe, 1956) and fluoresces (in the green region of visible light) in the presence of these cations at high $\mathrm{pH}$.
These stable fluorescent complexes are integrated in growing carbonates and have been used to stain the growth front of calcium carbonate surfaces in tufa-associated biofilms (Zippel and Neu, 2011) and in living microbialites from Alchichica, Mexico (Gérard et al., 2013). Microbialites samples from the BP mats were stained with calcein $\left(0.1 \mathrm{mg} / \mathrm{mL}\right.$; Merck) at $4^{\circ} \mathrm{C}$ during $48 \mathrm{~h}$. After staining, microbialite fragments were dehydrated in a gradual series of ethanol baths (30, 50, 70, 90, and 100\%), and progressively impregnated with hard grade LR-white resin (Polysciences, Inc.). After polymerization, transverse sections were cut with a diamond wire and polished (diamond powder $0.24 \mu \mathrm{m}$ ) to a final thickness of about $500 \mu \mathrm{m}$.

\section{Confocal Laser Scanning Microscopy (CLSM)}

Fresh BP microbial mat samples were stained with Syto ${ }^{\circledR} 9$ (10 $\mathrm{g} / \mathrm{mL}$; ThermoFisher Scientific), a green fluorescent nucleic acid dye. Syto ${ }^{\circledR} 9$-stained samples and resin-embedded microbial mat samples were examined at the Institut de Physique du Globe de Paris (IPGP, Paris, France) using a FluoView ${ }^{\mathrm{TM}}$ FV1000 confocal laser scanning microscope with a spectral resolution of $2 \mathrm{~nm}$ and a spatial resolution of $0.2 \mu \mathrm{m}$ (Olympus). The microscope was equipped with a $405 \mathrm{~nm}$ laser diode, and multiline argon $(458,488$, and $515 \mathrm{~nm})$, helium-neon-green $(543 \mathrm{~nm})$ and helium-neon-red $(633 \mathrm{~nm})$ lasers. Fluorescence images were 
obtained with concomitant excitation at wavelengths of 405, 488, and $543 \mathrm{~nm}$ by collecting the emitted fluorescence between 425 and $475 \mathrm{~nm}, 500$ and $530 \mathrm{~nm}$, and 560 and $660 \mathrm{~nm}$, respectively. For CSLM image acquisitions on resin-embedded sections, a water immersion LUMPLFL 60XW objective (Olympus; $\times 60$ magnification) with a numerical aperture (N.A.) of 0.9 was used. For fresh biofilms examination, an oil immersion objective UPLSAPO 60XO (Olympus; $\times 60$ magnification, N.A. $=1.35$ ) was used. 3D images were acquired, visualized, and processed using the F10-ASW FLUOVIEW software (Olympus).

\section{Bulk DNA Extraction, PCR Amplification, Cloning, and Sanger Sequencing of 165 rRNA Genes}

DNA extractions were performed using the MoBio PowerSoil ${ }^{\circledR}$ DNA kit (MoBio) following the instructions provided by the manufacturer. Bacterial 16S rRNA genes were amplified by polymerase chain reaction (PCR) using the bacterial specific primer 27F (5'-AGAGTTTGATCCTGGCTCAG-3') combined with the universal prokaryotic reverse primer $1492 \mathrm{R}$ (5'-GGTTACCTTGTTACGACTT-3'). Archaeal 16S rRNA genes were amplified using the archaeal specific primer $21 \mathrm{~F}$ $\left(5^{\prime}\right.$-TTCCGGTTGATCCTGCCGGA- $\left.{ }^{\prime}\right)$ and the prokaryote specific reverse primer 1492R. Cyanobacteria 16S rRNA genes were amplified using the cyanobacterial specific primers Cya-106F (5'-CGGACGGGTGAGTAACGCGTGA-3') and the cyanobacterial specific reverse primer Cya-1387R $\left(5^{\prime}-\right.$ TAACGACTTCGGGCGTGACC- $3^{\prime}$ ). One microliter of the extracted DNA was used in a reaction buffer volume of $25 \mu \mathrm{L}$ containing dNTPs (10 nmol each), 20 pmol of each primer and $1 \mathrm{U}$ GoTaq polymerase (Promega). PCR reactions were performed under the following conditions: 35 cycles (denaturation at $94^{\circ} \mathrm{C}$ for $15 \mathrm{~s}$, annealing at $55^{\circ} \mathrm{C}$ for $30 \mathrm{~s}$, extension at $72^{\circ} \mathrm{C}$ for $2 \mathrm{~min}$ ) preceded by $2 \mathrm{~min}$ denaturation at $94^{\circ} \mathrm{C}$, and followed by $7 \mathrm{~min}$ extension at $72^{\circ} \mathrm{C}$. Cloning was done using the Topo ${ }^{\circledR}$ TA Cloning ${ }^{\circledR}$ system (ThermoFisher Scientific) following the instructions provided by the manufacturer. After plating, positive clones were screened by PCR amplification of inserts using flanking vector primers and the PCR products were partially sequenced $(\approx 700 \mathrm{bp}$ ) by GATC Biotech using flanking vector primer T7 (5'-TAATACGACTCACTATAGGG-3'). At least one representative clone per phylotype or Operational Taxonomic Unit (OTU; group of sequences sharing $>97 \%$ identity) was fully sequenced for Cyanobacteria using flanking vector primer M13R (5'-CAGGAAACAGCTATGAC-3') for detailed phylogenetic analysis. The sequences have been deposited at the GenBank database and correspond to the accession numbers MH084957 to MH084967 for cyanobacteria, from MH109330 to 109371 for bacteria, and from MH127632 to MH127645 for archaea.

\section{Laser Microdissection, Whole Genome Amplification (WGA), PCR Amplification, Cloning and Sanger Sequencing of 165 rRNA Genes}

Filamentous cyanobacterial cells were isolated using a Zeiss PALM MicroBeam apparatus (Carl Zeiss NTS GmbH) installed in a sterile room at IPGP. We then used the REPLI-g Single Cell Kit (Qiagen) to amplify whole genomic DNA of the microdissected cells. Bacterial 16S rRNA encoding genes were then amplified by PCR using the bacterial specific primer 27F (5'-AGAGTTTGATCCTGGCTCAG-3') combined with the prokaryote specific reverse primer $1492 \mathrm{R}$ (5'-GGTTACCTTGTTACGACTT-3'). One microliter of $1 / 10$ diluted amplified genomic DNA was used in a reaction buffer volume of $25 \mu \mathrm{L}$ containing dNTPs (10 nmol each), $20 \mathrm{pmol}$ of each primer and $1 \mathrm{U}$ of GoTaq polymerase (Promega). PCR reactions were performed under the following conditions: 35 cycles (denaturation at $94^{\circ} \mathrm{C}$ for $15 \mathrm{~s}$, annealing at $55^{\circ} \mathrm{C}$ for $30 \mathrm{~s}$, extension at $72^{\circ} \mathrm{C}$ for $2 \mathrm{~min}$ ) preceded by $2 \mathrm{~min}$ denaturation at $94^{\circ} \mathrm{C}$, and followed by $7 \mathrm{~min}$ extension at $72^{\circ} \mathrm{C}$. Cloning and Sanger sequencing were done as previously described for the 16S rRNA encoding genes retrieved from the bulk DNA extraction. The corresponding sequences have been deposited at the GenBank database and accession numbers range from MH119800 to MH119817.

\section{PCR Amplification, Cloning, and Sanger Sequencing of Partial pufL and pufM Genes}

Partial pufL and pufM genes coding for subunits of the photosynthetic reaction center of aerobic anoxygenic photosynthetic bacteria (AAnPB; Koblizek, 2015) were amplified by nested PCR. The first amplification was done using the pufLM-F primer ( $5^{\prime}$-CTKTTCGACTTCTGGGTSGG-3') and the pufLM- $R$ primer ( $5^{\prime}$-CCCATSGTCCAGCGCCAGAA- $\left.3^{\prime}\right)(\mathrm{Oz}$ et al., 2005). One microliter of the DNA extracted from the bulk sample was used in a reaction buffer volume of $25 \mu \mathrm{L}$ containing dNTPs (10 nmol each), 20 pmol of each primer and $1 \mathrm{U}$ GoTaq polymerase (Promega). PCR reactions were performed under the following conditions: 40 cycles (denaturation at $94^{\circ} \mathrm{C}$ for $15 \mathrm{~s}$, annealing at $50^{\circ} \mathrm{C}$ for $30 \mathrm{~s}$, extension at $72^{\circ} \mathrm{C}$ for $2 \mathrm{~min}$ ) preceded by $2 \mathrm{~min}$ denaturation at $94^{\circ} \mathrm{C}$, and followed by $7 \mathrm{~min}$ extension at $72^{\circ} \mathrm{C}$. One microliter of the first amplification products was then used for the nested amplification with the primers Mf150f (5'-AGATYGGYCCGATCTAYCT-3') and M572r (5'-CCAGTCSAGGTGCGGGAA-3') (Hirose et al., 2012). The PCR conditions of the first amplification were also used for the nested PCR. As previously described for the 16S rRNA encoding genes, the pufLM genes were cloned using the Topo ${ }^{\circledR}$ TA Cloning ${ }^{\circledR}$ system (ThermoFisher Scientific) following the instructions provided by the manufacturer and the PCR products were totally sequenced by GATC Biotech using flanking vector primer T7 (5'-TAATACGACTCACTATAGGG-3') and M13R (5'-CAGGAAACAGCTATGAC-3'). The corresponding sequences have been deposited in the GenBank database and accession numbers range from MH101761 to MH101777.

\section{Phylogenetic Analysis}

Taxonomic affiliations were obtained using BLAST (Altschul et al., 1997) on the non-redundant NCBI database, as well as using the Silva Incremental Aligner (SINA) software (Pruesse et al., 2012). For Cyanobacteria, phylogenetic trees were built with the ARB software (Ludwig et al., 2004) and the SILVA 123 database (Quast et al., 2013; Yilmaz et al., 2014). Representative 
clones of the dominant phyla were aligned with SINA and then added in the ARB guide tree using the ARB parsimony tool. In addition, the closest environmental 16S rRNA gene sequences retrieved by BLAST were added if they were not present in the SILVA 123 database. Phylogenetic tree was reconstructed using the method of Randomized Accelerated Maximum Likelihood (RAxML) (Stamatakis et al., 2008) with the GTRCAT substitution model. Bootstrap values were calculated from 1,000 replicates.

The phylogenetic tree of partial pufLM operons was built using MEGA7 (Tamura et al., 2013), and the Maximum Likelihood method based on the Jukes-Cantor model (Jukes and Cantor, 1969). Initial tree(s) for the heuristic search were obtained automatically by applying Neighbor-Join and BioNJ algorithms to a matrix of pair wise distances estimated using the Maximum Composite Likelihood approach, and then by selecting the topology with the highest log likelihood value. The tree was drawn to scale, with branch lengths measured in the number of substitutions per site. The analysis involved 54 nucleotide sequences. Codon positions included were $1 s t+2 n d+3 r d+$ Noncoding. All positions containing gaps and missing data were eliminated. There were a total of 273 positions in the final dataset.

\section{Scanning Electron Microscopy (SEM)}

SEM analyses were performed on gold-coated air-dried samples using a Field Emission Zeiss Sigma Scanning Electron Microscope (Carl Zeiss NTS GmbH) at the X Ray Analysis Laboratory (LAMARX, Universidad Nacional de Córdoba, Argentina). SEM observation on carbon-coated samples dried at the critical point were also performed at the Service Commun de Microscopie Electronique à Balayage (UPMC, Paris, France) using a Zeiss Supra 55VP (Carl Zeiss NTS GmbH) SEM equipped with an EDXS spectrometer (X flash Quad detector, Brucker). Images were collected using secondary electron detectors (Everhart-Thornley for high voltage mode, VPSE for variable pressure mode and InLens for low voltage mode) and a backscattered electron detector (AsB). Accelerating voltage ranged from 3 to $15 \mathrm{kV}$ at variable pressures and high current (up to $1 \mathrm{nA}$ ).

\section{Mineralogical Identification}

Powder X-ray diffraction (XRD) analyses were conducted on BP microbial mat and lithified BP samples using a Philips PW1800/10 powder diffractometer equipped with a $\mathrm{Cu}$ anode and a graphite monochromator (LAMARX). Measurements were performed at $40 \mathrm{kV}$ voltage and $30 \mathrm{~mA}$ current, from 10 to $60^{\circ}(2 \theta)$, with an acquisition time of $2.0 \mathrm{~s}$ and an angular step of $0.100^{\circ} 2 \theta$. Resulting diffractograms were analyzed using Highscore software.

\section{Focused Ion Beam Milling (FIB) and Transmission Electron Microscopy (TEM)}

Eight ultrathin electron-transparent sections $(\sim 100 \mathrm{~nm}$ in thickness) were prepared by FIB milling on an Auriga ${ }^{\circledR}$ FIBSEM (Carl Zeiss NTS GmbH) available at IPGP using the FIB "lift out" technique (see Heaney et al., 2001 for details). A $30 \mathrm{kV}$ $\mathrm{Ga}^{+}$beam operated at $20 \mathrm{nA}$ was used for the initial steps of the milling. Progressive excavation from both sides of the section area was performed through repeated milling steps. Depth of milling was approximately 7 microns. The final thinning of the section was performed with a less intense $\mathrm{Ga}^{+}$beam operated at 100 pA current.

Transmission Electron Microscope (TEM) observations were carried out on all FIB sections using a JEOL $2100 \mathrm{~F}$ microscope (JEOL Ltd.) operating at $200 \mathrm{kV}$ at the Institut de Minéralogie, de Physique des Matériaux et de Cosmochimie (IMPMC, Paris, France). The TEM is equipped with a field emission gun, a ultrahigh resolution UHR pole piece and a Gatan energy filter. High-angle annular dark-field scanning transmission electron microscopy (HAADF-STEM) was used with a focused electron beam of a few $\mathrm{nm}$ for Z-contrast imaging. Energy Dispersive $\mathrm{X}$-ray Spectrometry (EDXS) analyses were performed using a JEOL detector equipped with an ultrathin window that allowed detection of low $\mathrm{Z}$ elements.

\section{Fourier Transform Infrared Microspectroscopy (FTIR)}

Cross-sections of oncoids associated with the black pustular mats were obtained using a sterilized diamond saw and sterile deionized water. They were prepared as doubly-polished sections of about $100 \mu \mathrm{m}$ thick and without any resin or glue in order to avoid organic contamination. FTIR hyperspectral images were acquired at IPGP using a Thermo Scientific iN10 MX microscope (Ever-Glo ${ }^{\mathrm{TM}}$ conventional Infrared source) with a liquid nitrogen cooled detector. Maps were collected in Attenuated Total Reflection (ATR) mode with a germanium tip. Punctual analyses were performed in the $4,000-700 \mathrm{~cm}^{-1}$ range, with a spot size of $20 \times 20 \mu \mathrm{m}$, a spectral resolution of $8 \mathrm{~cm}^{-1}$ and with 64 accumulations per spectrum. Background spectra were acquired between each spectrum under the same analytical conditions. Data were processed using the OMNIC ${ }^{\mathrm{TM}}$ software (Thermo Fisher Scientific).

\section{Synchrotron Based Deep UV Fluorescence Microspectroscopy (S-DUV)}

Slices from oncoid samples associated with black pustular mats were also investigated using synchrotron-based deep UV fluorescence microspectroscopy (S-DUV) and full-field imaging at the French national synchrotron radiation facility SOLEIL (Saint-Aubin, France) on the DISCO beamline (Giuliani et al., 2009). We focused on Rivularia-rich laminations in order to better describe the nature and spatial relationships between mineral phases and organic remnants at the micrometer scale. Both TELEMOS and POLYPHEME end stations available on the beamline were used. Samples were first investigated by fullfield luminescence microscopy (TELEMOS end station) using an Axio ObserverZ1 microscope (Carl Zeiss MicroImaging) with a $\times 40$ objective. The excitation wavelength was set at $275 \mathrm{~nm}$ with a DM300 dichroic mirror. Fluorescence emission was collected using 3 filters (bandpass at $327-353 \mathrm{~nm}, 370-410 \mathrm{~nm}$, and $420-480 \mathrm{~nm}$ ). Acquisition time was set at $30 \mathrm{~s}$ for all channels except for the $327-353 \mathrm{~nm}$ filter (60 s) and 2D fluorescence images were acquired along a transect, perpendicularly to 
the laminations of the oncoid sample. Images obtained with TELEMOS microscope were treated with ImageJ software (Schneider et al., 2012) and allowed localizing areas with the highest fluorescent signals. We then selected specific areas with Rivularia-like morphologies on which hyperspectral fluorescence maps were acquired (POLYPHEME end station) on an Olympus IX71 inverted microscope with homemade replacement of the intermediate lenses set to be transparent in the deep UV range (Jamme et al., 2010, 2013; Thoury et al., 2011) and a $\times 40$ objective. Excitation was set at $275 \mathrm{~nm}$ and a bypass mode was used in order to increase the intensity of the collected fluorescence signal. The collection range was set from 310 to $600 \mathrm{~nm}$. Spectra were processed using LabSpec software (Horiba Scientific).

\section{RESULTS}

\section{Description of the Microbial Mat and Associated Oncoids}

The microbial mat was characterized by a bulbous to pustular morphology (Figure 1C) and measured 1 to $8 \mathrm{~mm}$ in thickness. It had a dark pigmentation (Figures 1C,D), possibly due to the abundancy of scytonemin, a photoprotective pigment produced under high UV irradiation (Garcial-Pichel and Castenholz, 1991). No clear lamination was visible beneath the surface layer, although mixed green, pink and black patches along with white carbonated patches were detected (Figure 2A). Optical observation of this mat (Figure 2B) highlighted the predominance of large filamentous microorganisms resembling cyanobacterial Rivularia sp. (as confirmed by Sanger sequencing) and measuring around 12 to $15 \mu \mathrm{m}$ in diameter.

Irregular laminations with dark brown to yellowish vertically oriented Rivularia filaments $(15-20 \mu \mathrm{m}$ in diameter) were observed in petrographic sections of associated oncoids (Figure 2C). They alternated with micritic or botryoidal laminations. They presented a tufted paintbrush-like palisade fabric (Reitner et al., 1996). CLSM observations of these petrographic sections carried out at an excitation of $633 \mathrm{~nm}$ revealed a strong fluorescence of the Rivularia filaments within the paintbrush-like laminations (in red in Figure 2D). Some pigments were also observed near the filament sheaths using excitation at $543 \mathrm{~nm}$.

\section{Microbial Associations in BP Mats}

Conventional optical microscopy revealed the presence of a strongly mineralized microbial consortium associated with the Rivularia-like filaments. This latter included sulfur-bearing bacterial filaments and diatoms (Figure 3A). This consortium was also observed by CLSM. Filamentous cyanobacteria were identified based on the auto-fluorescence of their photosynthetic pigments (in red in Figure 3B). Numerous cocci (c1, c2, and $c 3$ ) and filamentous cells were also observed, fluorescing in green after Syto ${ }^{\circledR} 9$ staining. Among them, colonies of cells with a peculiar coccus shape (c1) were detected in close association with the Rivularia sheaths and the minerals (in light blue in Figure 3B). At high magnification, abundant microorganisms were observed in association with the thick sheath of a Rivularia filament (in green in Figure 3C). Rivularia cells were also visible (in red in Figure 3C). Consistently with conventional optical microscopy, filamentous sulfur-bearing bacteria were also detected in bright blue (laser reflection on the sulfur grains, Figure 3D) close to the Rivularia filaments. This was also confirmed by SEM imaging highlighting elemental sulfur grains on these filaments (SF. in Figure 3E). No precipitated mineral was detected in close relationship with the Rivularia sheaths.

\section{Microbial Diversity}

In order to characterize the microorganisms forming the consortium associated with the Rivularia filaments and to assess their potential role in mineral precipitation, 16S rRNA gene sequences of Bacteria and Archaea were analyzed for the BP mat samples collected in 2013 and 2015. Results obtained from either laser microdissected cyanobacterial filaments collected in 2015 or bulk DNA extractions on all samples are summarized in the following sections.

\section{Laser Microdissection and Whole Genome Amplification of Rivularia Filaments and of the Associated Bacterial Consortium}

After laser microdissection of large filamentous cyanobacteria, we detected three different representative $16 \mathrm{~S}$ rRNA gene sequences (3c-25, 3c-38, and 3c-57) of cyanobacteria affiliated to the Rivularia genus (Table 1). 16 sequences represented by $3 c-25$ and 3c-57 shared 99\% identities with the 16S rRNA gene sequence of Rivularia detected in a microbial mat associated with the microbialites of Alchichica Lake (JN825310) and Rivularia atra BIR MGR1 (AM230675), a marine species forming black colonies (Guiry and Morrison, 2015) and Calothrix sp. XP9A (AM230670). 14 sequences represented by 3c-38 share $100 \%$ identities with Rivularia sp. PUNA_NP3_PCI185B (KY296608) isolated from Laguna Negra microbial mat. Heterotrophic Bacteroidetes affiliated to Marivirga (Pagani et al., 2011), Maribacter and Winogradskyella genera constituted the most abundant epiphytic bacterial community associated with the Rivularia filaments (Table 1). No archaeal sequences were detected within the consortium, hence suggesting that archaea were not closely associated with the Rivularia filaments.

\section{Bulk DNA Extraction}

After bulk DNA extraction, cyanobacteria affiliated to the Rivularia genus were detected in both mats collected in 2013 and 2015 using cyanobacterial specific primers (Figure 4) but not using universal bacterial primers. The $16 \mathrm{~S}$ rRNA gene sequences of Rivularia species detected in 2015 (BP2015-9*) were identical to the $3 c-25$ sequences detected after whole genome amplification (Figure 4). Yet, the most abundant cyanobacterial 16S rRNA gene sequences detected using cyanobacterial specific primers were affiliated to the Phormidium genus for both 2013 and 2015 (Figure 4). The clones were notably affiliated to Phormidium sp. MBIC10210 LEGE 11384 and Phormidium lucidum CY-012 (JQ927355 and KC217548, respectively; 98\% to 99\% identities). 17 sequences from 2015 were also closely related to sequences detected in microbialites from Alchichica, an alkaline Mexican lake (Halomicronema sp., JN825328; 97\% identity). 


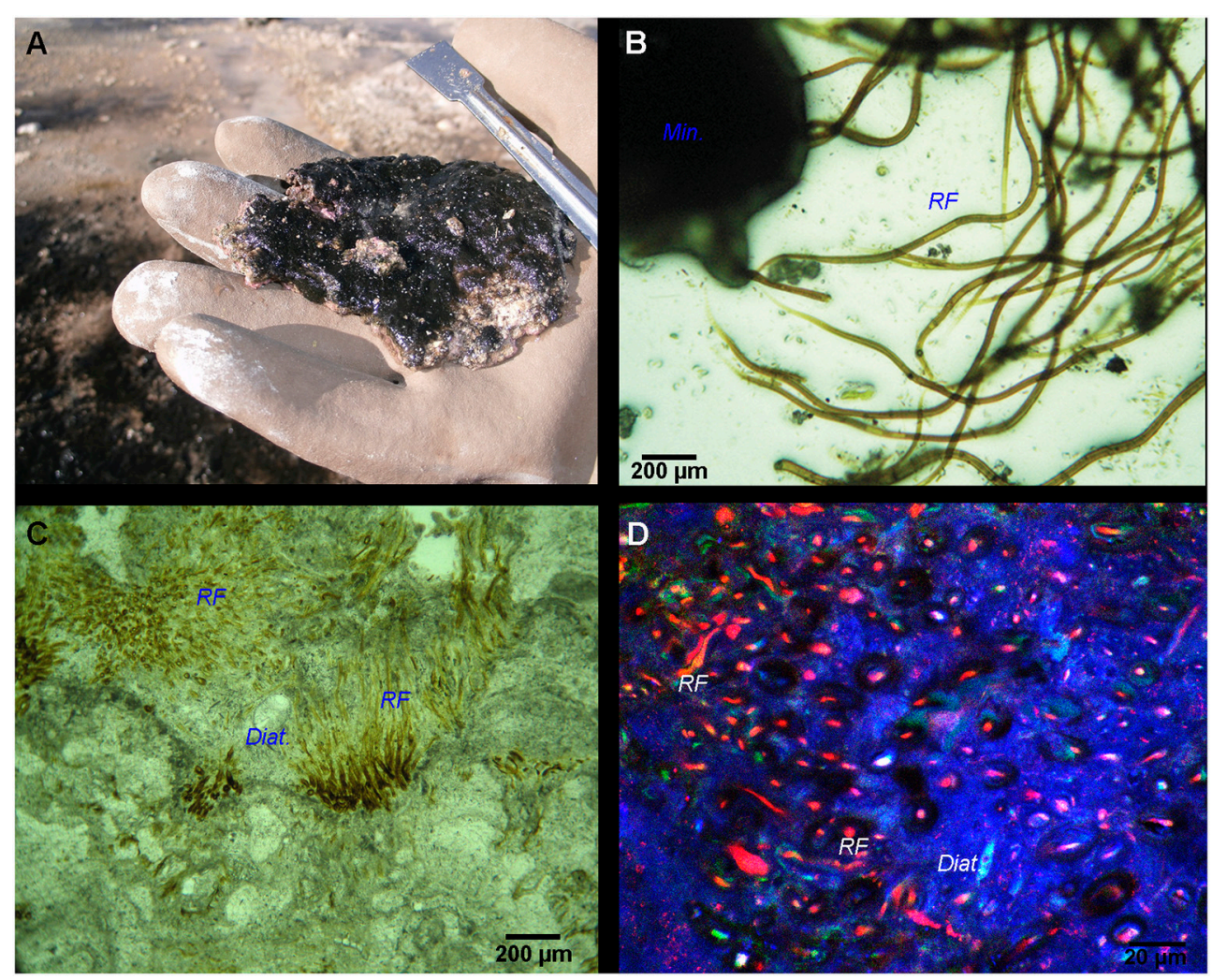

FIGURE 2 | (A) Black pustular mat with visible white-colored carbonate precipitates. (B) Optical microscopy image of the BP mat highlighting Rivularia filaments (RF) associated with minerals (Min.). (C) Paintbrush-like palisade fabric of Rivularia-like filaments encrusted by carbonates and preserved inside an oncoid lamination alternating with other lamination types (like sparry, botryoidal and micritic). Encrusted diatoms (Diat.) can also be found. (D) CLSM image of the same lamination enclosing Rivularia-like filaments whose remaining pigments show red fluorescence. The mineralized portion of the oncoid appears in blue due to laser reflection on solid carbonates.

A description of the main bacterial sequences detected in 2013 and 2015 using general bacterial primers is given in Table 2. Bacteroidetes, Proteobacteria and Verrucomicrobia were the most abundantly detected phyla. Only one sequence of cyanobacteria was detected. Among the bacterial phyla, Bacteroidetes belonging to the Lewinella genus were identified. Their cultivable representatives (Lewinella cohaerens, Lewinella persica) correspond to orange to black chemoorganotrophic bacteria (Khan et al., 2007). Interestingly, members of the Gammaproteobacteria found in both 2013 and 2015, samples have closest uncultivated bacteria (98\% identities) that were only detected in the Altiplano at Salar de Ascotan in Chile (EF632661). Bacteria belonging to the Myxococcales order were also observed in both samples. They were affiliated to bacteria from the semiarid "Tablas de Dainiel National Park" wetland (Central Spain, FJ516764).

The other detected bacterial species were specific to the BP mats collected in 2013 or 2015 . In the BP mat collected in 2013, numerous bacteria affiliated to marine species were identified. Bacteroidetes closely related to Winogradskyella echinorum (JQ661183, 97\% identity; Nedashkovskaya et al., 2009) were detected. Most of the observed Alphaproteobacteria clones belonged to the Rhodobacteraceae family. One OTU was closely related to the Tropicibacter genus (97\% identity; Lucena et al., 2013) and another one to Sulfitobacter noctilucicola (NR_134206, 99\% identity; Kwak et al., 2014). An additional member of Alphaproteobacteria was closely related (98\% identity) to the aerobic phototrophic marine bacteria Marivita cryptomonadis (NR_044514). Finally, Verrucomicrobia members affiliated to the Haloferula genus were distinguished. They were close to Haloferula chungangensis (NR_109435), a heterotrophic ureolytic bacterium from marine sediments (Kang et al., 2014). Conversely, the sulfur-bearing filamentous cells observed using CLSM and SEM in association with Rivularia (Figures 3A,D,E) were not clearly identified in our $16 \mathrm{~S}$ rRNA gene sequences retrieved by bulk DNA extraction. Although the unidentified sulfur-bearing filament bacteria were morphologically similar to Thiotrix species (Howarth et al., 1999), further efforts will be required to identify them by testing new protocol of DNA extraction retrieving additional 16S rRNA encoding gene sequences and performing laser microdissection.

In the BP mat collected in 2015, several detected bacteria were closely related to uncultivated bacteria from the Guerrero Negro hypersaline microbial mats belonging to Bacteroidetes (JN453999), Alphaproteobacteria (JN530502, JN436614) and Verrucomicrobia (JN480742). Other identified Bacteroidetes 


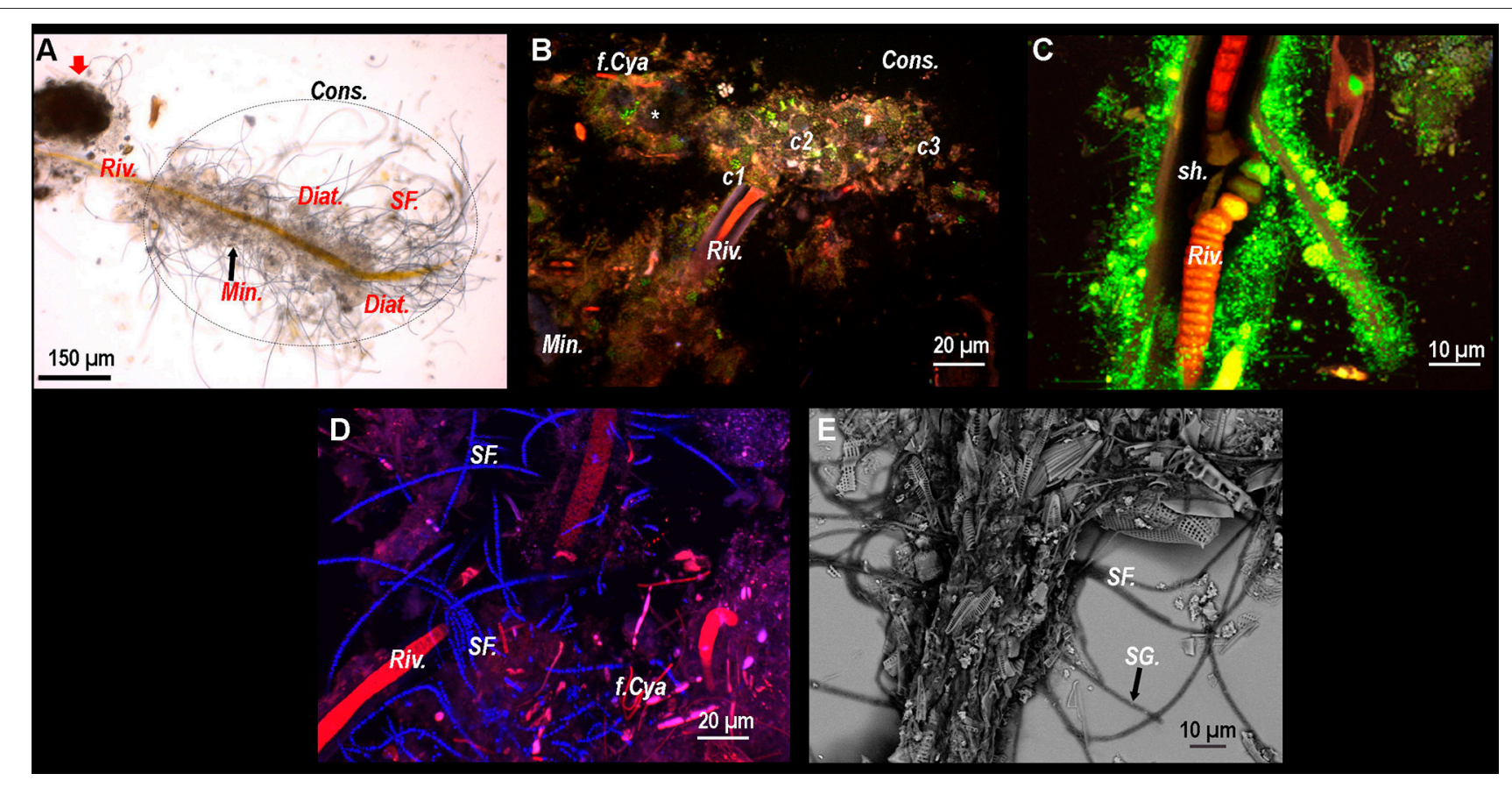

FIGURE 3 | (A) Optical microscopy image of a Rivularia filament (Riv.) with which numerous microorganisms are associated, hence suggesting the presence of a consortium (Cons.) (dotted circle). A large mineral aggregate is also visible near the filament (red arrow). Sulfur filaments (SF.), diatoms (Diat.) and mineral grains (Min.) can also be observed around the filament. From (B-D): Composite CSLM images obtained over an integrated depth of $50 \mu \mathrm{m}$ by concomitant excitations at 405 , 488, and $543 \mathrm{~nm}$ and collection between 425 and $475 \mathrm{~nm}, 500$ and $530 \mathrm{~nm}$, and 560 and 660 nm, respectively. (B) Composite CLSM image of a consortium surrounding a Rivularia filament distinguished in red due to its photosynthetic pigments. Inside the consortium, abundant cocci-shaped cells are observed thanks to Syto ${ }^{\circledR} 9$ staining (green) (c1, c2, and c3). Minerals appear in light blue due to laser reflection (white asterisk). Other filamentous cyanobacteria ( $\left.f . C y a\right)$ are observed. (C) High magnification composite CLSM image of a Rivularia filament where cells are visible (in red) inside the sheath (sh.), which is covered by a myriad of Syto ${ }^{\circledR} 9$-stained cells. (D) Detail of a Rivularia filament associated with sulfur-bearing bacterial filaments (bright blue dots due to laser reflection). (E) Magnified SEM image in backscattered electron mode showing a Rivularia filament and the associated sulfur-bearing filaments (black arrow) with sulfur grains (SG.) appearing as bright dots. (A,B,D,E) were obtained on BP13 mat samples, while (C) was observed on BP15 mat sample after laser microdissection.

were close to bacteria from El Tatio hot springs (GU437622), a high altitude (4400 meters above sea level) geothermal site with low sulfide and high arsenic concentrations in Chile (Engel et al., 2013). These Bacteroidetes were also related to Psychroflexus salinarum (NR108235; 96\% identity), which correspond to dark orange bacteria isolated from marine solar saltern (Yoon et al., 2008). Moreover, three bacterial sequences affiliated to Bacteroidetes already found associated with diatom detritus were also observed in this sample (AY298788; 98\% identity). Similarly to the results obtained for the 2013 BP mat, several sequences affiliated to the Roseobacter clade were detected and belonged to the Oceanicola genus (98\% identities, KY770546), the Octadecabacter genus (98\% identity with KX073749) and the Roseinatronobacter genus (97\% identities with KJ486297), all these bacteria being aerobic phototrophic bacteria.

As observed for Bacteria, the Archaea communities were clearly different in BP mats collected in 2013 and in 2015 (Table 3). In 2013 BP samples, we detected only methanogenic archaea. Sequences affiliated to the obligate acetoclastic methanogenic Methanosaeta harundinacea (Ma et al., 2006) (CP003117, 99\% identity). In addition, some sequences were related to Methanolinea tarda (NR_028163, 97\% identity), a strain using $\mathrm{H}_{2}$ and formate for growth and methane production (Imachi et al., 2008). Diverse other methanogenic archaea were detected, notably some closely affiliated to Methanogenium cariaci (99\% identities) a marine methanogenic archaea (N_104730, 99\% identities), which uses hydrogen and carbon dioxide as substrates for growth (Romesser et al., 1979). In 2015 BP, the archaea detected were affiliated to the Thermoplasmatales order. The sequences were related to $16 \mathrm{~S}$ rRNA gene sequences of uncultivated archaea retrieved in hypersaline mats (EU585947, EU585956, HM480251).

\section{pufLM Genes Cluster Detection}

The phylogenetic analysis of the puflM genes cluster detected in 2013 (BP13) showed that at least 18 different sequences of aerobic anoxygenic phototrophic bacteria $(\mathrm{AAnPB})$ were present in the analyzed BP mat. As also noticed for the 16S rRNA encoding genes, two groups of AAnPB seemed to be endemic of high altitude Andean lakes as the partial pufLM sequences were close to sequences detected in a high altitude salt lake in Chile (FN813741 and FN813748) (Figure 5).

\section{Associated Carbonate Minerals in BP Mats}

Most of the Rivularia filaments were observed in the superficial pustular zone of the BP mats. They showed a tangled 
TABLE 1 | Taxonomic affiliations of the bacterial 16S rRNA gene sequences retrieved using general bacterial primers after laser microdissection from the BP consortia collected in 2015.

\begin{tabular}{|c|c|c|c|c|}
\hline & Taxonomy & $\mathrm{Nb}$ & Closest environmental bacteria & Closest cultivated bacteria \\
\hline $4 c-1$ & Bacteroidetes; Flammeovirgaceae; Marivirga & 4 & & KT324862 100\%, Marivirga sp. CR-23 \\
\hline $4 c-14$ & Bacteroidetes; Flammeovirgaceae; Marivirga & 5 & $\begin{array}{l}\text { AF170787 98\%, Antarctic quartz stone } \\
\text { sublithic communities }\end{array}$ & $\begin{array}{l}\text { NR112183 98\%, Marivirga sericea strain } \\
\text { IFO } 15983\end{array}$ \\
\hline $3 c-4$ & Bacteroidetes; Flavobacteriaceae & 3 & $\begin{array}{l}\text { AF170787 96\%, phycosphere of } \\
\text { Enteromorpha prolifera }\end{array}$ & $\begin{array}{l}\text { JQ069961 96\% Maribacter sp. } \\
\text { BSw21901 }\end{array}$ \\
\hline $3 c-13$ & Bacteroidetes; Flavobacteriaceae; Maribacter & 3 & & JQ988061 99\%, Maribacter sp. T28 \\
\hline $3 c-34$ & Bacteroidetes; Flavobacteriaceae & 2 & & $\begin{array}{l}\text { NR_043453 99\%, Psychroserpens } \\
\text { mesophilus }\end{array}$ \\
\hline $3 s-2$ & Bacteroidetes; Flavobacteriaceae & 8 & & $\begin{array}{l}\text { JQ } 687107 \text { 99\%, Winogradskyella sp. } \\
\text { KYW } 630\end{array}$ \\
\hline $3 s-13$ & $\begin{array}{l}\text { Bacteroidetes; Flavobacteriaceae; } \\
\text { Winogradskyella }\end{array}$ & 4 & & $\begin{array}{l}\text { NR_137338 95\%, Winogradskyella } \\
\text { litoriviva }\end{array}$ \\
\hline $3 c-11$ & $\begin{array}{l}\text { Bacteroidetes; Flavobacteriaceae; } \\
\text { Winogradskyella }\end{array}$ & 1 & KY190901 95\%, marine sediment, Antartica & $\begin{array}{l}\text { AY771731 95\%, Winogradskyella } \\
\text { thalassocola }\end{array}$ \\
\hline $3 c-25$ & Cyanobacteria; SubsectionIV; Familyll; Rivularia & 14 & $\begin{array}{l}\text { JN825310 99\%, microbialites from Alchichica } \\
\text { alkaline lake }\end{array}$ & AM230675 99\%, Rivularia atra BIR MGR1 \\
\hline $3 c-38$ & Cyanobacteria; SubsectionIV; Familyll; Rivularia & 14 & & $\begin{array}{l}\text { KY296608 100\%, Rivularia sp. } \\
\text { PUNA_NP3_PCl185B }\end{array}$ \\
\hline $3 c-57$ & Cyanobacteria; SubsectionIV; Familyll; Rivularia & 2 & $\begin{array}{l}\text { JN825310 99\%, microbialites from Alchichica } \\
\text { alkaline Lake }\end{array}$ & AM230670 99\%, Calothrix sp. XP9A \\
\hline $3 c-51$ & $\begin{array}{l}\text { Cyanobacteria; Subsectionl; Familyl; } \\
\text { Gloeocapsa }\end{array}$ & 3 & $\begin{array}{l}\text { GQ340127 98\%, water column Marathonas } \\
\text { Reservoir }\end{array}$ & GQ375048 98\%, Limnococcus limneticus \\
\hline $3 c-43$ & Proteobacteria; Gammaproteobacteria; HTA4 & 2 & JQ586297 98\%, arctic marine sediment & $\begin{array}{l}\text { EF492067 97\%, Candidatus Berkiella } \\
\text { cookevillensis }\end{array}$ \\
\hline $3 s-16$ & $\begin{array}{l}\text { Proteobacteria; Gammaproteobacteria; } \\
\text { Legionellaceae; Legionella }\end{array}$ & 2 & & LT906452 96\%, Legionella pneumophila \\
\hline $4 c-9$ & Unclassified & 6 & AB630669 96\%, aquatic moss pillars & \\
\hline $3 c-15$ & Unclassified & 3 & KJ998102 97\%, Guerrero Negro intertidal mat & \\
\hline $3 c-45$ & Unclassified & 1 & KJ998102 95\%, Guerrero Negro intertidal mat & \\
\hline
\end{tabular}

Nb stands for number of clones.

arrangement with variable amounts of EPS-associated mineral aggregates and diatoms located between the cyanobacterial filaments (Figure 6A). The lower (i.e., inner) part of the BP mats showed Rivularia filaments together with calcium carbonate precipitates within an EPS matrix and diatoms (Figure 6B). Locally and within the carbonates, some tubular hollow structures were observed (Figure 6B). They probably corresponded to entombed microbial filaments. The diameter of these hollow structures was variable, being similar or lower than that of fresh Rivularia filaments (Figure 6B).

XRD analyses of bulk samples of the BP mats showed that they were mainly composed of $\mathrm{Mg}$-calcite, with a lower amount of aragonite (Supplementary Figure S1). At the microscale, as observed using SEM, different types of carbonate particles were identified, with the predominance of sub-spherical to subhedral carbonate particles with diameters varying from 80 to $700 \mathrm{~nm}$ (Figure 6C) along with almost perfect tiny carbonate spheres (Figure 6E). Occasionally more irregular anhedral carbonate particles of similar size were also observed (Figure 6D). Subspherical to subhedral particles were typically associated with EPS and sometimes clustered into irregularly shaped aggregates of various sizes (usually up to $\sim 200 \mu \mathrm{m}$ in diameter). These aggregates were closely associated to the EPS matrix where abundant diatoms and other microorganisms were also present (Figures 6C-F). They occasionally clumped together and form wavy to irregularly shaped horizontal lamina.

Another distinct group of calcium carbonate particles was represented by irregular bunches of elongated, needle- and spindle-like particles (Figure 6F). The individual needle-shaped particles could be up to $2 \mu \mathrm{m}$ long and formed irregularly distributed clusters or patches that were not typically associated with the EPS matrix. As suggested by XRD data and given the acicular shape these particles, these needles could be aragonite. While the precipitation of the nanometer-sized sub-spherical to spherical calcium carbonate grains appeared to be limited to the EPS matrix of the top-most layers of the mat, the larger subhedral and euhedral grains were mostly present in the inner parts of the mat, where degraded diatoms and cyanobacterial sheaths were present.

\section{Calcein Staining of Resin-Embedded BP Mat: Calcium Localization}

In order to study the micro-scale relationships between microorganisms and carbonate precipitates within the consortium, resin-embedded microbial mat fragments stained with calcein were analyzed by CLSM. Calcein stained the 


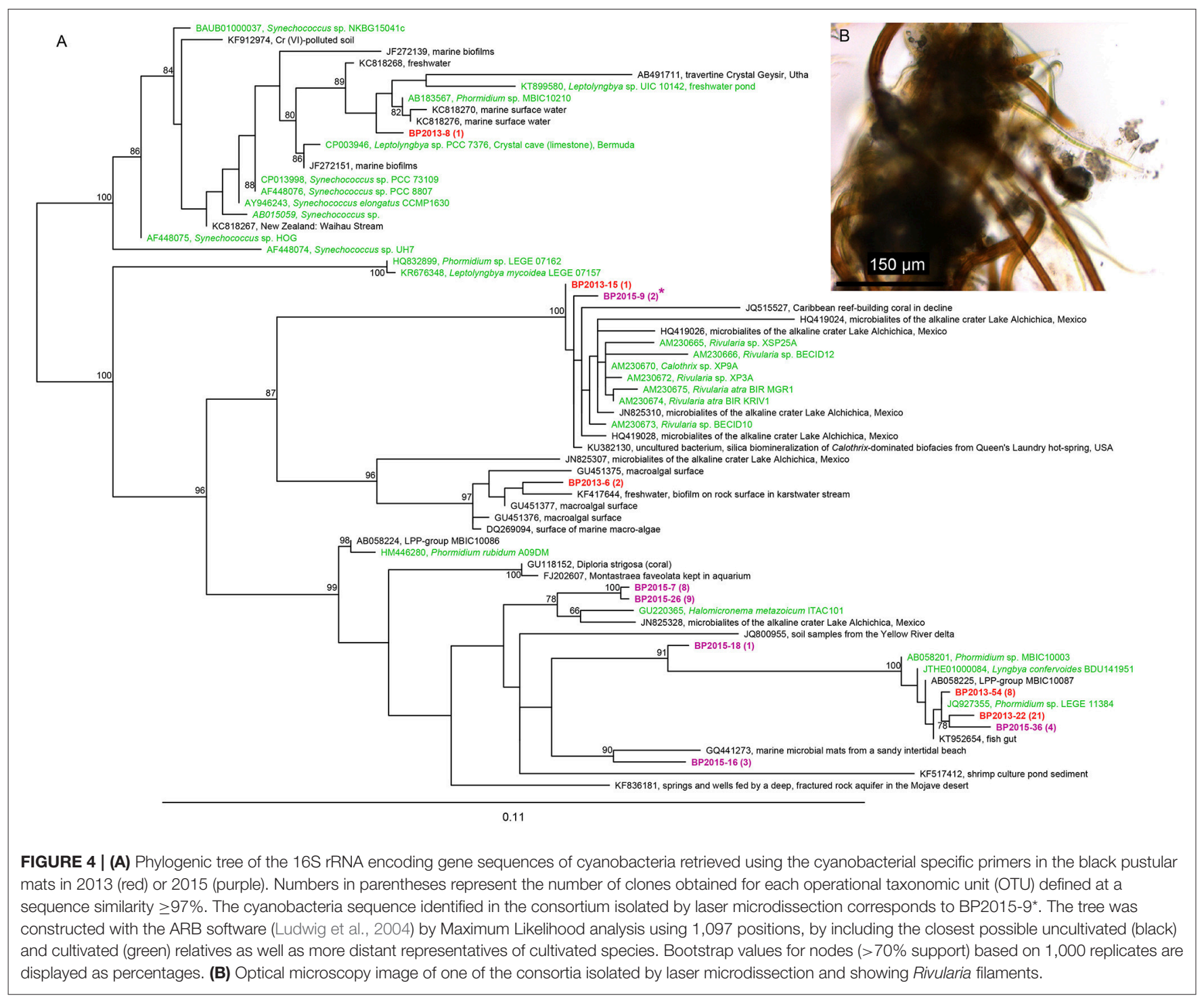

active parts of mats displaying free divalent cations close to the minerals and the subspherical aggregates located in between the Rivularia filaments (Figures 7A,B). Besides, the cocci cells $(c 1)$ already observed in Figure 3, were also visible with abundant calcein staining around the colonies (Figure 7B), all in close spatial relationship with the Rivularia sheaths (Figure 7D). Interestingly, calcein accumulated in between the Rivularia sheaths and cells (Figures 7A-D). Some bright spots were also detected at this level (Figures 7B-D), suggesting a possible mechanism of calcium accumulation or trafficking. As only $\mathrm{Ca}^{2+}$ was detectable using SEM-EDXS around the cells stained with calcein (Supplementary Figure S2), this calcein coloration should mainly reveal $\mathrm{Ca}^{2+}$ accumulation rather than $\mathrm{Mg}^{2+}$ accumulation.

\section{Transmission Electron Microscopy Observations of a Cyanobacterial Filament}

In order to explore the possibility of calcium accumulation inside the filaments, as suggested by the bright spots observed in Figures 7B-D, FIB ultrathin sections were milled from resinembedded BP mat samples showing calcein-stained Rivularia filaments. This procedure allowed exploring the free $\mathrm{Ca}$ and $\mathrm{Mg}$ content of cyanobacterial sheaths without any interference coming from the surrounding minerals.

A longitudinal Rivularia filament stained with calcein was selected with others for FIB milling after CLSM observation (Supplementary Figure S3 and Figure 8A) and transversally milled (Figure 8B). HAADF-STEM observation of the FIB section with associated STEM-EDXS mapping of calcium (Ca, yellow) and carbon (C, red), is shown in Figures 8C,D. These two elements exhibited opposite distributions. Calcium-rich areas (white and black dotted lines) corresponded to lowcarbon areas. Localized calcium globules were also detected (black and white arrows in Figures 8C,D, respectively). No clear or very low Mg signal was detected in the analyzed samples, supporting the idea of $\mathrm{Ca}$ accumulation within the filaments. These observations were consistent with CLSM observations showing high calcein fluorescence between the Rivularia sheaths 
TABLE 2 | Taxonomic affiliations of the bacterial 16S rRNA gene sequences using general bacterial primers retrieved from the BP mats collected in 2013 (gray) and 2015 (white).

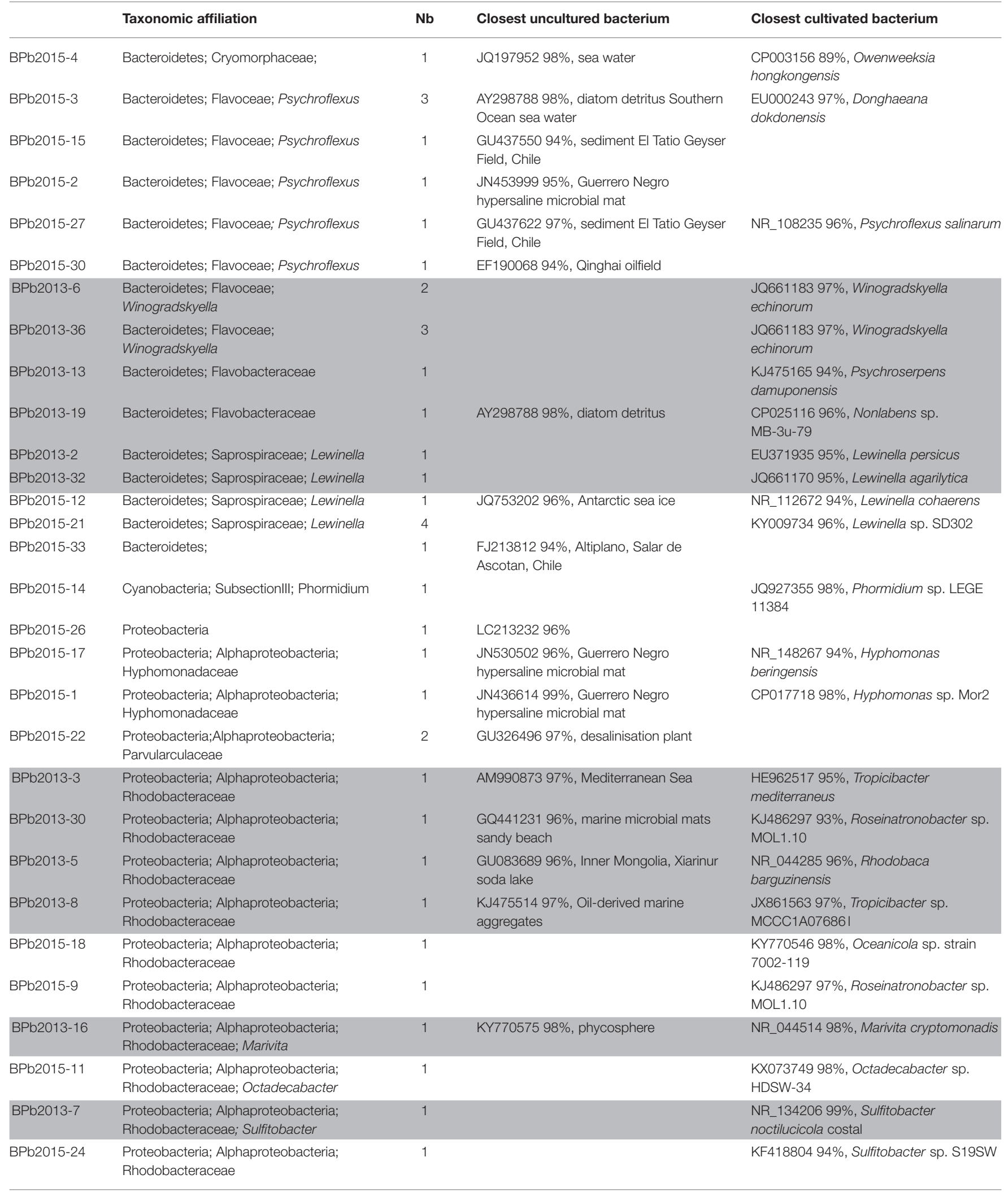


TABLE 2 | Continued

\begin{tabular}{|c|c|c|c|c|}
\hline & Taxonomic affiliation & $\mathrm{Nb}$ & Closest uncultured bacterium & Closest cultivated bacterium \\
\hline BPb2015-6 & $\begin{array}{l}\text { Proteobacteria; Gammaproteobacteria; } \\
\text { Alteromonadaceae; Marinobacter }\end{array}$ & 1 & & $\begin{array}{l}\text { NR_145917 93\%, Marinobacter } \\
\text { confluentis }\end{array}$ \\
\hline BPb2013-11 & $\begin{array}{l}\text { Proteobacteria; } \\
\text { Gammaproteobacteria; }\end{array}$ & 1 & $\begin{array}{l}\text { EF632661 98\%, Chile: Altiplano, Salar } \\
\text { de Ascotan }\end{array}$ & \\
\hline BPb2015-34 & $\begin{array}{l}\text { Proteobacteria; } \\
\text { Gammaproteobacteria; }\end{array}$ & 1 & $\begin{array}{l}\text { EF632661 98\%, Chile: Altiplano, Salar } \\
\text { de Ascotan }\end{array}$ & \\
\hline BPb2015-28 & & 1 & & \\
\hline BPb2015-23 & $\begin{array}{l}\text { Proteobacteria; Gammaproteobacteria; } \\
\text { Oceanospirillaceae;Nitrincola }\end{array}$ & 1 & & FJ764761 96\%, Nitrincola sp. E-044 \\
\hline BPb2015-5 & $\begin{array}{l}\text { Proteobacteria; Gammaproteobacteria; } \\
\text { OM182 clade }\end{array}$ & 1 & HM127577 98\%, Qinghai Lake & $\begin{array}{l}\text { NR_112620 91\%, Thioprofundum } \\
\text { hispidum }\end{array}$ \\
\hline BPb2013-28 & Proteobacteria; Gammaproteobacteria & 1 & $\begin{array}{l}\text { EF632659 99\%, aquatic environment } \\
\text { Altiplano Chile }\end{array}$ & $\begin{array}{l}\text { MG264256 98\%, Wenzhouxiangella } \\
\text { marina }\end{array}$ \\
\hline $\begin{array}{l}\text { BPb2015-55- } \\
\text { CYA }\end{array}$ & $\begin{array}{l}\text { Proteobacteria; Deltaproteobacteria; } \\
\text { Myxococcales }\end{array}$ & $7^{*}$ & $\begin{array}{l}\text { FJ516764 97\%, wetland (Central } \\
\text { Spain) }\end{array}$ & \\
\hline BPb2013-14-CYA & $\begin{array}{l}\text { Proteobacteria; Deltaproteobacteria; } \\
\text { Myxococcales }\end{array}$ & $6^{*}$ & $\begin{array}{l}\text { FJ516764 99\%, wetland (Central } \\
\text { Spain) }\end{array}$ & \\
\hline BPb2013-10 & $\begin{array}{l}\text { Verrucomicrobia; Verrucomicrobiaceae; } \\
\text { Haloferula }\end{array}$ & 3 & $\begin{array}{l}\text { KY190897 95\%, marine sediment from } \\
\text { Potter Cove }\end{array}$ & $\begin{array}{l}\text { NR_109435 95\%, Haloferula } \\
\text { chungangensis }\end{array}$ \\
\hline BPb2015-7 & Verrucomicrobia & 2 & $\begin{array}{l}\text { JN480742 96\%, Guerrero Negro } \\
\text { hypersaline microbial mat }\end{array}$ & \\
\hline
\end{tabular}

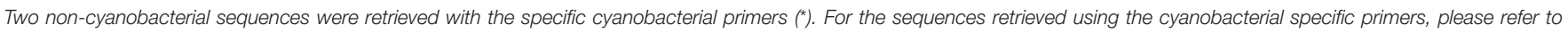
Figure 4. Strictly identical sequences retrieved in BP2013 and BP2015 are indicated in bold. Nb stands for number of clones.

and the cells. Nevertheless, in this case no crystalline phase was detected inside the Rivularia sheaths or cells.

\section{Characterization of the Structure and Mineralogy of Rivularia-Rich Laminations in Oncoids Associated With the BP Mats}

SEM and CLSM observations indicated that, in the mat, carbonate precipitation seemed to occur within the EPS excreted by the microbial consortium found associated with the Rivularia filaments, which dominate the black pustular mat. The corresponding laminations within the associated oncoids should then be considered as biologically-induced and may have then registered direct or indirect traces of biological activity. We then investigated these laminations in oncoids in order to characterize potential biomarkers to be searched for in fossil stromatolites. Synchrotron-based deep UV fluorescence imaging was first carried out on a cross-section from an oncoid associated with the BP mats collected in 2013 (Figure 9). Optical microscopy observations of this cross section highlighted the presence of different laminations presenting variable colors (Figure 9A). Among them, brown-beige laminations were clearly distinguishable from other ones and were marked by the presence of numerous encrusted Rivularia-like filaments (Figure 9A). Full-field fluorescence images were collected on a transect crossing Rivularia-rich laminations (Figure 9B) after excitation at $275 \mathrm{~nm}$. Similar imaging was performed on other Rivulariarich laminations (Figure 9C) for consistency. Reconstructed RGB images indicated that the fluorescence signal was different in these laminations compared to the bulk carbonated matrix of the oncoid (in white in Figure 9A). These laminations (Figure 9B images 2 and 4, and Figure 9C) display fluorescence emission in the range $327-357 \mathrm{~nm}$ (detected with the Blue filter) while white laminations were dominated by a mix of fluorescence emission signals collected with the green and red filters (leading to a yellow color; Figures 9B,C). These observations were consistent for the whole sample and indicated that Rivularia-rich laminations presented a different structure or composition compared to the other laminations. In order to decipher the origin of this specific signal, hyperspectral fluorescence images were acquired on the same sample. An example of the collected fluorescence emission signal is given Figure 9C. Spectra were characterized by two bands at 316 and $341 \mathrm{~nm}$ and a large massif above $400 \mathrm{~nm}$. The latter one could not be properly deconvoluted due to optical artifacts occurring above $400 \mathrm{~nm}$. The two other bands at 316 and $341 \mathrm{~nm}$ were likely emerging from organic compounds related to cell remnants (main fluorescence emission at 312, 340 , and $410 \mathrm{~nm}$; Jamme et al., 2013) trapped in the mineralized matrix. The difference in fluorescence emission signals observed between Rivularia-rich laminations and other laminations could then correspond to a different content in organic compounds. However, carbonate minerals are known to fluoresce when excited in the UV range. The variable fluorescence patterns from one lamination to another one might then also be induced by differences in the lamination mineralogy.

The mineralogy of Rivularia-rich laminations was then investigated. Bulk XRD analyses were first performed on powdered oncoid associated with BP mat (Figure 10A) and indicated the predominance of $\mathrm{Mg}$-rich calcite (90\%) associated with minor aragonite (10\%). Microscale ATR-FTIR analyses were then performed on the cross-section analyzed by S-DUV 
TABLE 3 | Taxonomic affiliations of the archaeal 16S rRNA gene sequences using general archaeal primers retrieved from the BP mats collected in 2013 (gray) and 2015 (white). Nb stands for number of clones.

\begin{tabular}{|c|c|c|c|c|}
\hline & Taxonomic affiliation & $\mathrm{Nb}$ & Closest uncultured archaeon & Closest cultivated archaeon \\
\hline 2015BPar-1 & unclassified & 1 & $\begin{array}{l}\text { EU585947 95\%, hypersaline } \\
\text { microbial mat }\end{array}$ & \\
\hline 2015BPar-21 & $\begin{array}{l}\text { Euryarchaeota; Thermoplasmatales; Marine Benthic } \\
\text { Group D and DHVEG-1 }\end{array}$ & 2 & $\begin{array}{l}\text { EU585947 99\%, hypersaline } \\
\text { microbial mat }\end{array}$ & \\
\hline 2015BPar-30 & $\begin{array}{l}\text { Euryarchaeota; Thermoplasmatales; Marine Benthic } \\
\text { Group D and DHVEG-1 }\end{array}$ & 2 & $\begin{array}{l}\text { EU585956 98\%, hypersaline } \\
\text { microbial mat }\end{array}$ & \\
\hline 2015BPar-19 & $\begin{array}{l}\text { Euryarchaeota; Thermoplasmatales; Marine Benthic } \\
\text { Group D and DHVEG-1 }\end{array}$ & 1 & $\begin{array}{l}\text { EU585961 96\%, hypersaline } \\
\text { microbial mat }\end{array}$ & \\
\hline 2015BPar-16 & $\begin{array}{l}\text { Euryarchaeota; Thermoplasmatales; Marine Benthic } \\
\text { Group D and DHVEG-1 }\end{array}$ & 1 & $\begin{array}{l}\text { EU585964 97\%, hypersaline } \\
\text { microbial mat }\end{array}$ & \\
\hline 2015BPar-13 & $\begin{array}{l}\text { Euryarchaeota; Thermoplasmatales; Marine Benthic } \\
\text { Group D and DHVEG-1 }\end{array}$ & 1 & $\begin{array}{l}\text { HM480251 99\%, hypersaline } \\
\text { microbial mat }\end{array}$ & \\
\hline 2015BPar-9 & $\begin{array}{l}\text { Euryarchaeota; Thermoplasmatales; Marine Benthic } \\
\text { Group D and DHVEG-1 }\end{array}$ & 1 & $\begin{array}{l}\text { EU585964 98\%, hypersaline } \\
\text { microbial mat }\end{array}$ & \\
\hline 2013BPar-30 & $\begin{array}{l}\text { Euryarchaeota; Methanosarcinales; } \\
\text { Methanosaetaceae; Methanosaeta }\end{array}$ & 1 & $\begin{array}{l}\text { HG001405 99\%, salt marsh } \\
\text { sediment }\end{array}$ & CP003117 98\%, Methanosaeta harundinacea \\
\hline 2013BPar-26 & $\begin{array}{l}\text { Euryarchaeota; Methanosarcinales; } \\
\text { Methanosaetaceae; Methanosaeta }\end{array}$ & 6 & $\begin{array}{l}\text { KX581173 99\%, marine } \\
\text { sediment }\end{array}$ & CP003117 99\%, Methanosaeta harundinacea \\
\hline 2013BPar-3 & $\begin{array}{l}\text { Euryarchaeota; Methanosarcinales; } \\
\text { Methanosarcinaceae; }\end{array}$ & 2 & $\begin{array}{l}\text { KP987245 99\%, subsurface } \\
\text { sediments }\end{array}$ & KF952458 95\%, Methanosalsum zhilinae \\
\hline 2013BPar-24 & $\begin{array}{l}\text { Euryarchaeota; Methanosarcinales; } \\
\text { Methanosarcinaceae; }\end{array}$ & 3 & $\begin{array}{l}\text { KP987245 99\%, subsurface } \\
\text { sediments }\end{array}$ & NR_102894 97\%, Methanosalsum zhilinae \\
\hline 2013BPar-2 & $\begin{array}{l}\text { Euryarchaeota; Methanomicrobiales; } \\
\text { Methanoregulaceae; Methanolinea }\end{array}$ & 2 & $\begin{array}{l}\text { MG062727 99\%, anaerobic } \\
\text { granules }\end{array}$ & NR_112799 96\%, Methanolinea mesophila \\
\hline 2013BPar-9 & $\begin{array}{l}\text { Euryarchaeota; Methanomicrobiales; } \\
\text { Methanoregulaceae; Methanolinea; }\end{array}$ & 6 & $\begin{array}{l}\text { AB236052 98\%, marine } \\
\text { sediment }\end{array}$ & NR_028163 97\%, Methanolinea tarda \\
\hline 2013BPar-11 & $\begin{array}{l}\text { Euryarchaeota; Methanomicrobiales; } \\
\text { Methanomicrobiaceae; Methanogenium }\end{array}$ & 2 & & NR_104730 99\%, Methanogenium cariaci \\
\hline
\end{tabular}

fluorescence imaging, specifically in the areas presenting a "blue" fluorescence pattern (Figure 9B images 2 and 4, and Figure 9C). Most of the acquired ATR-FTIR $\operatorname{spectra}(n \approx$ 66) presented a similar pattern and are summarized in Figure 10B. The position of main $\mathrm{CO}_{3}{ }^{2-}$ vibrational bands $\left(v_{2}\right.$ asymmetric bending at $870 \mathrm{~cm}^{-1} ; \nu_{3}$ asymmetric stretching at $1,400 \mathrm{~cm}^{-1} ; \nu_{1}+\nu_{4}$ at $1,800 \mathrm{~cm}^{-1}$ ) were compared to carbonate standards and mainly corresponded to calcite (e.g., spectra a and b in Figure 10B). Some spectra presented patterns that might indicate a mixed composition between calcite and other carbonates depending on the position in the lamination. The low spatial resolution of the ATR tip $(20 \times 20 \mu \mathrm{m})$ precluded the identification of individualized pure components at the microscale. However, some spectra acquired very close to Rivularia-like cell remnants presented shifts from the typical calcite $\nu_{2}$ asymmetric bending band at $1,789 \mathrm{~cm}^{-1}$ (vs. $1,796 \mathrm{~cm}^{-1}$ for calcite), along with a marked shoulder in the $\nu_{3}$ asymmetric stretching band (black arrow in spectrum $c$ displayed in Figure 10B). It should correspond to a mix between calcite and aragonite. Similarly, analyses in a white lamination, far from the assumed influence of Rivularia-rich lamination, presented a shift of the $v_{2}$ asymmetric bending toward $1,803 \mathrm{~cm}^{-1}$. It may highlight a mixed composition between calcite and dolomite (spectrum $\mathrm{d}$ in Figure 10B) and should be indicative of the presence of
Mg-bearing carbonate, consistently with bulk XRD analyses. These combined analyses seem to confirm that the Rivularia-rich laminations should be distinguishable from the other ones from a spectroscopic point of view. Even if we cannot non-ambiguously conclude, they may present a higher organic content than other laminations (without Rivularia filaments) and/or a different mineralogy.

\section{DISCUSSION}

The different microscopic observations and microbial diversity analyses carried out in this study highlight the likely influence of the microbial consortium observed around Rivularia filaments in the carbonate precipitation process. Thus, the role of Rivularia and of the related consortium in the mineralization processes is discussed. In parallel, the composition of the corresponding laminations in oncoids, comparatively to other laminations, is discussed in order to characterize potential biosignatures to be searched for in fossil stromatolites.

The most abundantly detected cyanobacterial 16S rRNA gene sequences using the cyanobacterial specific primer were affiliated to the Phormidium and Rivularia genus. The large filamentous cyanobacteria of around $15 \mu \mathrm{m}$ in diameter, observed by optical microscopy and CLSM, were identified as Rivularia using laser microdissection (Table 1, Figure 4). A striking observation is that 


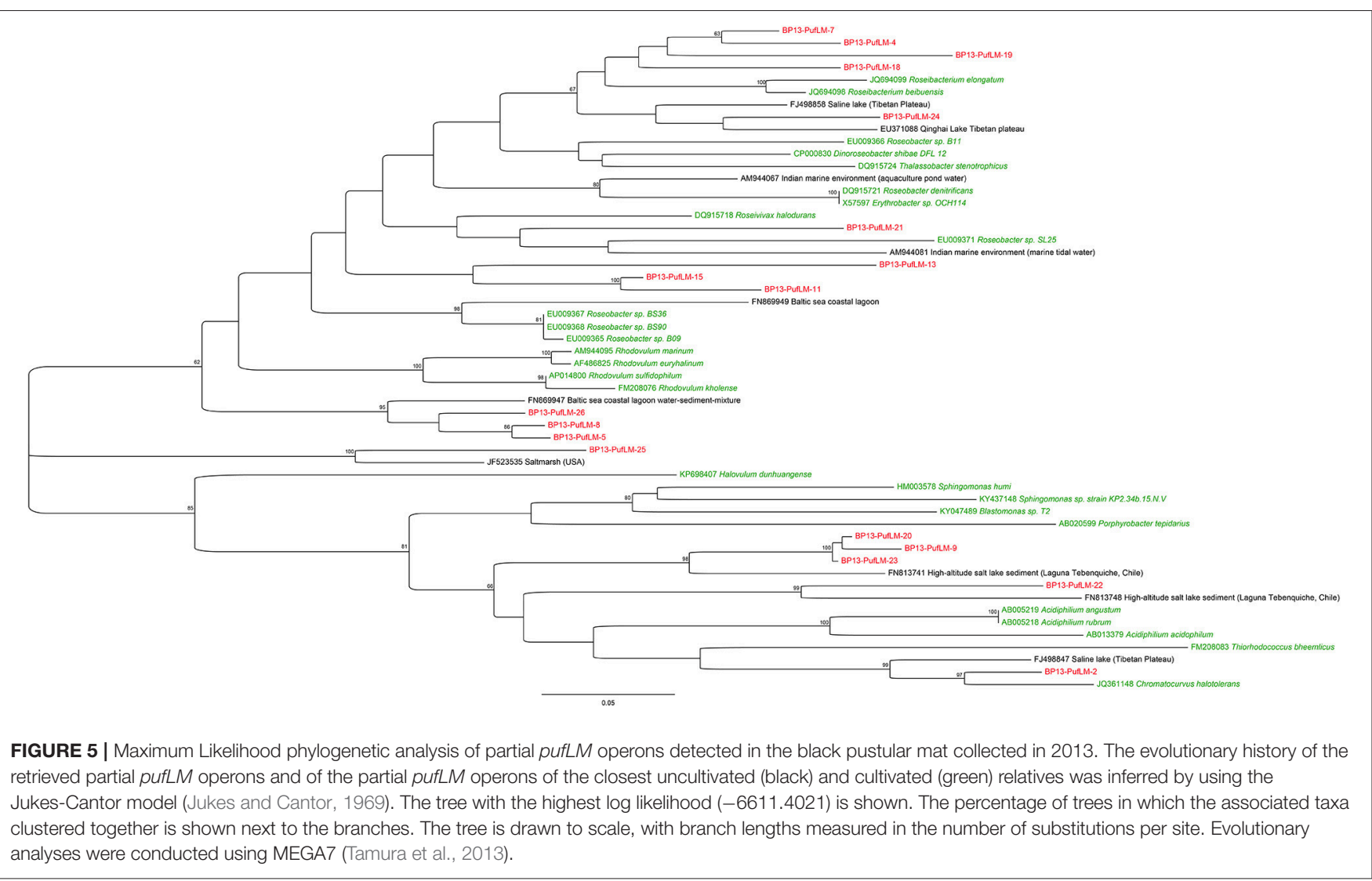

calcein stained the space between the cells and the sheath of the Rivularia filaments (Figure 7). It suggests a possible mechanism of $\mathrm{Ca}^{2+}$ concentration and may have implications for carbonate precipitation. This could be due to the difference between the cell wall and the sheath surface that was observed for Calothrix sp. (strain KC97; Phoenix et al., 2002), a cyanobacteria presenting a morphology similar to the one of the Rivularia sp. Calothrix sp. has a spatially dual-layer system composed of a reactive cell wall, and a poorly-reactive sheath. The sheath may then inhibit detrimental biomineralization or $\mathrm{HCO}_{3}{ }^{-}$diffusion. On the contrary, the cell wall, which contains a high density of electronegative sites, may trap cations (Phoenix et al., 2000, 2002). A similar process should be proposed for the Rivularia of Laguna Negra. It would explain the specific accumulation of $\mathrm{Ca}^{2+}$ observed close to the cell wall surface rather than on the external sheath itself. Conversely, it has been shown that living cyanobacterial cells are capable of self-protection against solid carbonate incrustation through shedding of mineralized S-layer (Thompson et al., 1997; Douglas and Beveridge, 1998) and/or by metabolically maintaining positive surface potential to avoid $\mathrm{Ca}^{2+}$ adsorption and subsequent entombment within solid carbonates (Martinez et al., 2008, 2010). On the other hand, in cyanobacteria, as for all organisms, intracellular calcium is strongly regulated by independent processes of $\mathrm{Ca}^{2+}$ uptake and active efflux (Smith and Wilkins, 1988). The normal levels of $\mathrm{Ca}^{2+}$ are maintained very low in order to prevent toxicity. If external $\mathrm{Ca}^{2+}$ concentrations are higher, as it is typically the case in hypersaline lakes, calcium uptake may involve low passive permeability of $\mathrm{Ca}^{2+}$ sensitive trans-membrane channels (Singh and Mishra, 2014). In the case of the Andean Rivularia sp. identified in this study, further efforts should be devoted to understand why Rivularia filaments are capable to keep free $\mathrm{Ca}^{2+}$ ions between the cells and the sheaths without inducing carbonate precipitation, and if this calcium could bind to the Slayer domains (e.g., glutamate and aspartate residues) or to the cell wall domains to control the flux of calcium in and out of cells.

Despite the alkalinizing activity of Rivularia cyanobacteria and contrary to what was described for freshwater Rivularia (Pentecost and Ulrich, 2010), a remarkable observation of the present study is that the Rivularia filaments did not present any carbonate precipitation close to their sheath (Figures 3, 6, 7). Calcification in cyanobacteria depends on local environmental conditions (Arp et al., 2001; Riding, 2006) and only occurs in waters supersaturated with respect to calcium carbonates. However, only certain genera calcify and none of them are obligate calcifiers (Merz, 1992). The microorganisms located on the cyanobacterial sheath may metabolically modify the local physico-chemical conditions and induce or preclude carbonate precipitation. We assessed the influence of the activity of epiphytic bacteria on carbonation, based on the results obtained by $16 \mathrm{~S}$ rRNA encoding genes sequencing following laser microdissection and whole genome amplification. Most of the bacteria associated with the Rivularia sheaths were affiliated to known epiphytic members of the Bacteroidetes phylum. Some identified species were affiliated to the Maribacter genus that 


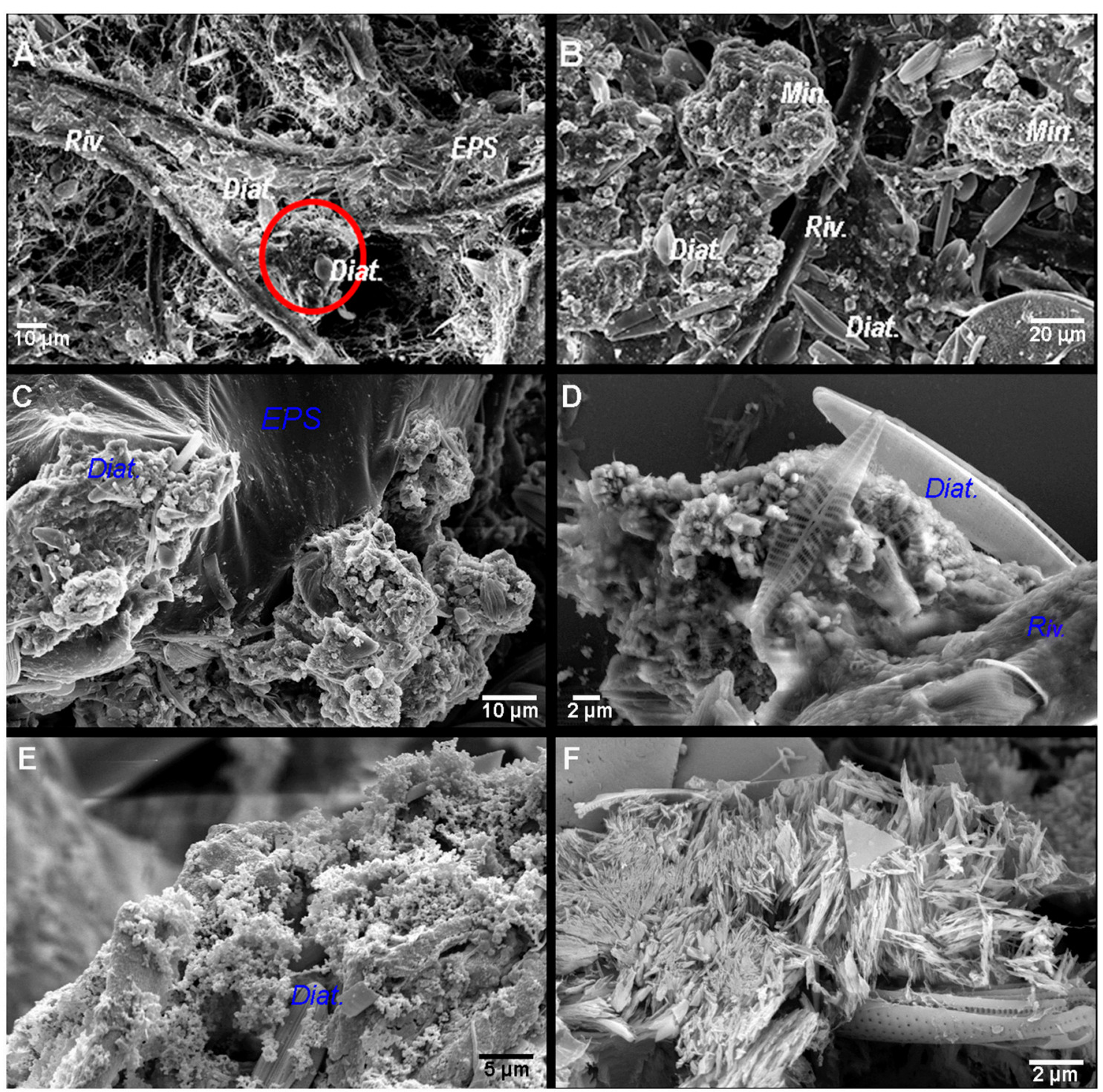

FIGURE 6 | (A) SEM images of the surface of the black pustular mat where Rivularia filaments (Riv.) and exopolymeric substances (EPS) are observed. The red circle highlights a mineral aggregate with diatoms (Diat.). (B) Below the black pustular surface, mineral aggregates (Min.) with diatoms are abundant; some Rivularia filaments can also be observed. From (C-D), SEM images in backscattered electron mode of the carbonate minerals associated with the Rivularia filaments in BP mats. (C) Aggregates formed by sub-spherical to subhedral carbonate particles associated with the EPS matrix where diatoms frustules are also observed.

(D) Magnified view of a mineral aggregate with subspherical carbonate grains and associated diatoms. (E) Aggregate composed of submicrometric carbonate spherules entombing abundant diatoms frustules. (F) Elongated needle-like carbonates.

encompasses heterotrophic bacteria associated with brown algae (Nedashkovskaya et al., 2004). Their activity may accordingly induce acidic conditions by producing $\mathrm{CO}_{2}$ around Rivularia sheaths, hence precluding carbonate precipitation (Dupraz and Visscher, 2005; Dupraz et al., 2009) and explaining the absence of carbonation on Rivularia sheaths in Laguna Negra.

On the contrary, the results obtained in this study indicated that carbonate precipitation occurred within the EPS matrix excreted by the diverse bacterial consortium associated with Rivularia. To identify potential calcifiers in the BP mats, the influence of the whole microbial community retrieved by bulk phylogenetic analyses was then assessed in light of microscopic observations. SEM and CLSM observations indicated that calcification might start with the precipitation of small isolated granules of calcium carbonates dispersed throughout the EPS matrix surrounding diatoms and coccoid pigmented cells (c1) (Figures 3, 7) but not in direct contact with the Rivularia sheath. Diatoms and other microorganisms such as Myxococcales and methanogenic archaea are known to produce large amounts of EPS (Bapteste et al., 2005; Scholten et al., 2005). These EPS should serve as nucleation sites for carbonate precipitation following organo-mineralization 


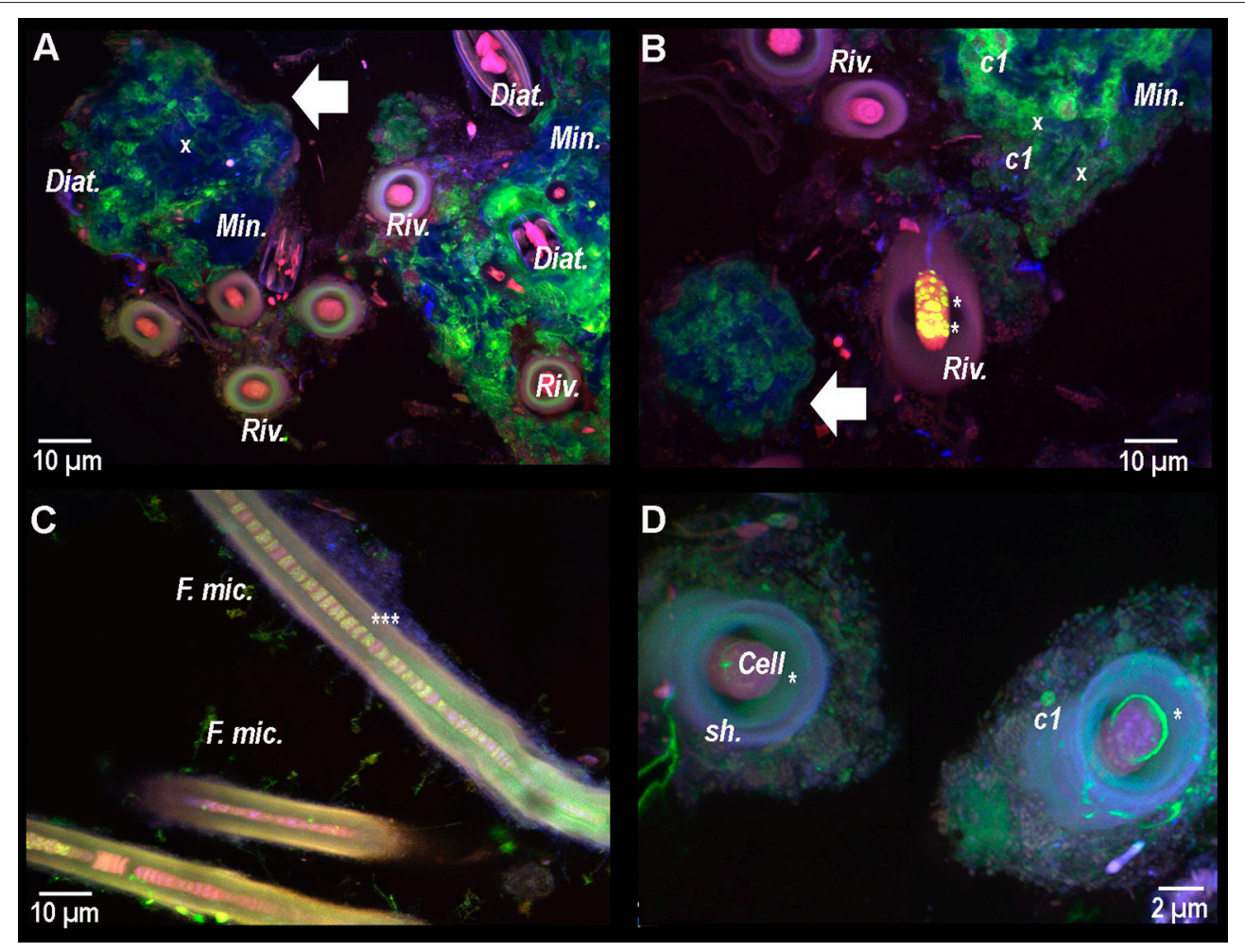

FIGURE 7 | Composite CLSM images of a resin-embedded black pustular microbialite, stained with calcein. Images were obtained with concomitant excitations at 405, 488, and $543 \mathrm{~nm}$ and collection between 425 and $475 \mathrm{~nm}, 500$ and $530 \mathrm{~nm}$, and 560 and 660 nm, respectively. Fluorescence emission between 500 and $530 \mathrm{~nm}$ emerges specifically from calcein (in green). (A) Mineral aggregates (Min. and white arrow) are observed in blue. Their surfaces are partially stained with calcein, hence indicating the presence of free $\mathrm{Ca}^{2+}$ ion. Inside and surrounding the mineral aggregate, diatom frustules (x) and living diatoms (Diat.) are visible thanks to their photosynthetic pigments. Some Rivularia filaments (Riv.) seem to be separated from the mineralized aggregates, while other filaments are close but not entombed in the aggregate and occur with diatoms. Calcein stained the space inside the filaments, i.e., between the sheath and the cells. In (B) yellow/light green dots are observed in one of the Rivularia filament (*). Calcein also strongly stained the contours of the pigmented c1 cocci-shaped cell colonies that were found closely associated with the mineral aggregates (white arrow). (C) Close up view of calcein-stained Rivularia filaments. The dye also stained some other filamentous microorganisms associated with the Rivularia sheath (F. mic.). Inside the Rivularia filament, some green dots are distinguishable ( $\left.{ }^{\star \star \star}\right)$. (D) Image of two transversally-cut Rivularia filaments, where calcein fluorescence $\left({ }^{*}\right)$ was also found between the cells and the sheath (sh.); as in (C), calcein also stained the c1 colonies.

processes (Perry et al., 2007; Defarge et al., 2009). This is consistent with the micritic anhedral globular textures observed by SEM, characteristic of carbonate precipitation occuring in an organic matrix (Dupraz et al., 2009). The primary amorphous grains would be bound to EPS surface charges and would then grow into larger subhedral to euhedral carbonate grains. The precipitation of these carbonates would be favored by the supersaturation of the waters relatively to calcite (Gomez et al., 2014) and by some local alkalinization induced by microbial activity. Notably, in addition to the photosynthetic activity of Rivularia, diatoms may also have promoted local alkalinization. Furthermore, some of the bacteria identified in the whole microbial community may present potential alkalinizing metabolisms favoring carbonate precipitation. Among them are the Myxococcales identified in the BP mats of Laguna Negra. Some bacteria belonging to this order are known to favor mineral precipitation (Jimenez-López et al., 2007), such as Myxococcus xanthus, which induces carbonate precipitation by ammonification, resulting in an increase of the alkalinity in the culture medium (González-Muñoz et al., 2010). Of likely greater interest, the pigmented coccoid bacteria (c1, Figure 3) may correspond to some of the aerobic anoxygenic phototrophic bacteria (AAnPB) affiliated to the marine Roseobacter clade (Figure 5 and Table 2). Abundant and diverse AAnPB were detected in the BP mats (Table 2). The phylogenetic analysis of the 16S rRNA and pufLM encoding genes showed that specific AAnPB develop in hypersaline high altitude Andean lakes. Members of the Roseobacter clade are known to interact with marine phytoplankton, including diatoms, also abundant in Andean lakes (Maidana and Seeligmann, 2006; Farías et al., 2013, 2014; Barbieri et al., 2014). This association may allow microbes to use metabolic niches that would be inaccessible otherwise (Overmann and van Gemerden, 2000; Schink, 2002; Orphan et al., 2008). For example, Roseobacter-related species are able to use glycolate excreted by eukaryotic phytoplankton during autotrophic photorespiration (Fogg, 1983; Grossart et al., 2005). Members of the Roseobacter clade are phototrophic bacteria but lack genes for inorganic carbon fixation (Lenk et al., 2012; Luo and Moran, 2014; Zhang et al., 2016). Consequently, these bacteria cannot favor carbonate precipitation via alkalinization 


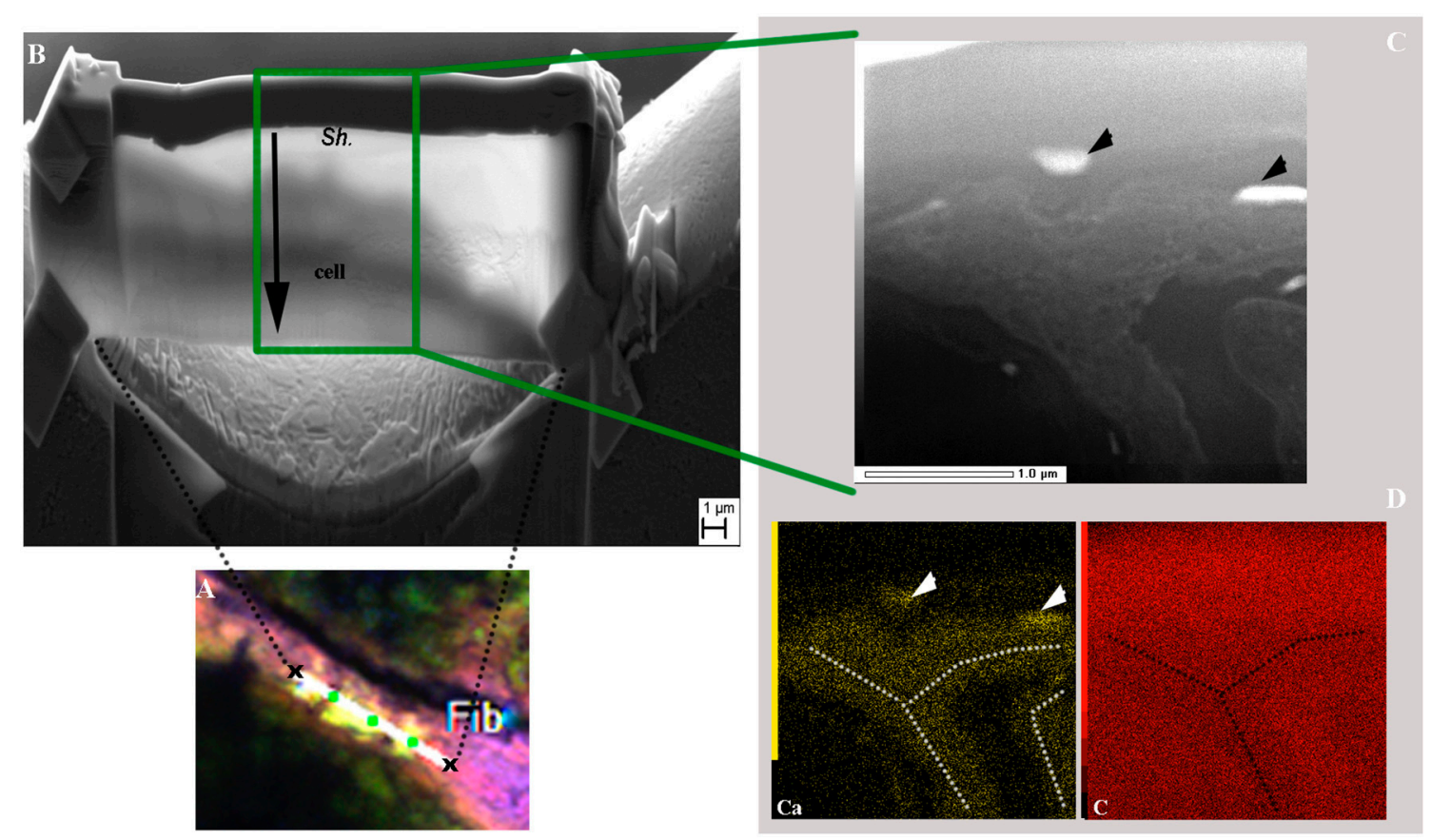

FIGURE 8 | SEM and TEM observations of a FIB section longitudinally milled on a cyanobacteria filament stained with calcein as shown in the CLSM image displayed in (A) (see Supplementary Figure S3 for location of the selected area and associated scale). (B) SEM image of the ultrathin section after milling. The upper part of the section corresponds to the filament sheath (Sh.) and the lower part (end of black arrow) to the cyanobacteria cell. (C) HAADF-STEM image of the FIB section showing the filament along its longer axis and the different phases within the filament. The black arrowheads indicate regions with strong electron absorption. (D) Associated STEM-EDXS elemental maps for calcium (Ca; in yellow) and carbon (C; in red) displaying opposite distributions. Ca-rich areas are highlighted by white arrowheads and white dotted lines.

linked to photoautotrophy (Dupraz and Visscher, 2005). On the contrary, most of the members of the Roseobacter clade are ureolysers and some are denitrifyers (Luo and Moran, 2014). Both ureolysis (Zhu and Dittrich, 2016) and denitrification (Erşan et al., 2015) increase $\mathrm{pH}$ in the surrounding medium and favor carbonate precipitation. Furthermore, it has been shown that denitrification activity of the Roseobacter denitrificans strain was increased by light stimulus (Doi and Shioi, 1991). Even if we cannot preclude the influence on carbonate formation of other microbial strains, such as methanogenic archaea (Michaelis et al., 2002; Roberts et al., 2004; Scholten et al., 2005; Kenward et al., 2009), we suggest that phototrophy, ureolysis and denitrification associated with the activity of AAnPB may be important drivers of alkalinization and carbonate precipitation in the BP mats of Laguna Negra.

Overall, Rivularia cyanobacteria favored the development of a large microbial consortium that indirectly promoted carbonate precipitation via organo-mineralization processes, and hence participated to the formation of stromatolites. The corresponding laminations in oncoids should then be considered as biologicallyinduced. They may present some direct or indirect markers of biological activity or cell remnants that may furnish biosignatures that could be searched for in the geological record. We then investigated stromatolites associated to the black pustular mat at Laguna Negra. We focused on laminations that presented
Rivularia-like encrusted cells and we compared them to micritic and botryoidal laminations of the stromatolites, which may have a purely chemical origin. The laminations of interest presented well-preserved filaments that may have been encrusted in vivo or rapidly after death while preserving the original sheath morphology and sizes (Riding, 1977; Merz-Prei and Riding, 1999; Couradeau et al., 2014). The morphology of the mat could indeed be preserved if the carbonate formation process is fast enough to cover the EPS (Kazmierczak et al., 2015), hence creating mineral coatings on cells or groups of cells. Besides, these encrusted filaments presented a strong fluorescence signal after CLSM that could be attributed to cell photosynthetic pigments (Figure 2D). Pigments are recalcitrant molecules that can be preserved in sediments (Leavitt et al., 1997). They could be used as molecular fossils of photosynthetic organisms (Brocks and Pearson, 2005). The analysis of the Rivularia-rich laminations of oncoids associated with BP mats using S-DUV also clearly highlighted a different fluorescence signal compared to other laminations after excitation in the deep UV range (Figure 9). The origin of the fluorescence pattern could not be fully elucidated but could be attributed either to (i) a different mineralogy or (ii) a higher content in organic compounds trapped in the mineral matrix relatively to other laminations. Punctual FTIR analyses of the Rivularia-like laminations seemed to indicate a possible higher proportion of aragonite relatively to calcite or $\mathrm{Mg}$-calcite 


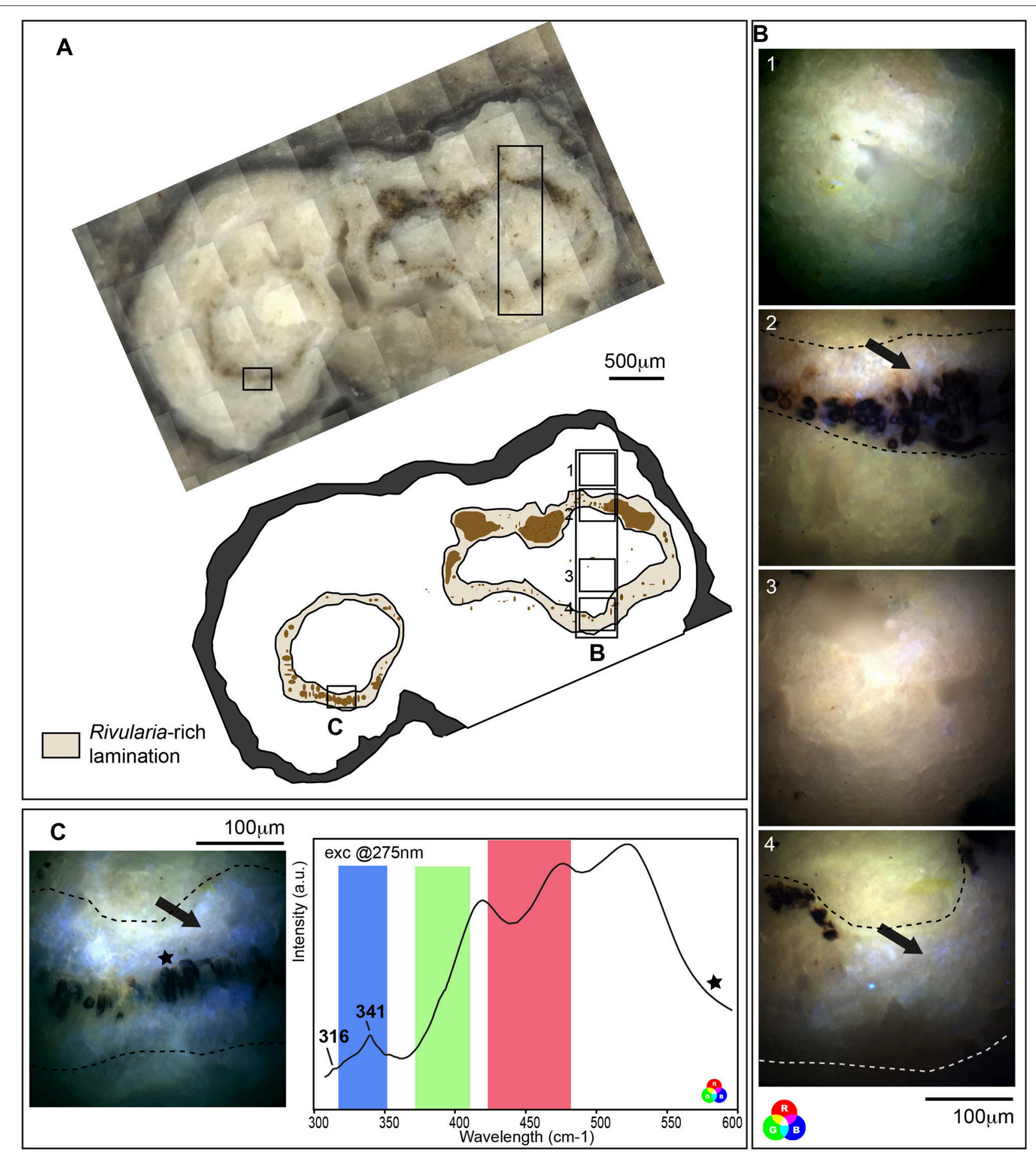

FIGURE 9 | Fluorescence emission signal after synchrotron-based deep UV excitation at $275 \mathrm{~nm}$ of a cross section of an oncoid associated with a black pustular mat. (A) Optical microscopy observation and schematic representation of the cross section highlighting Rivularia-rich laminations with encrusted Rivularia-like cells. The localization of areas of interest analyzed by S-DUV fluorescence imaging is given. (B) Composite RGB images of 4 areas of interest were reconstructed using the fluorescence signal collected with filters between 327 and $353 \mathrm{~nm}$ (Blue), 370 and $410 \mathrm{~nm}$ (Green) and 420 and $480 \mathrm{~nm}$ (Red). They were surimposed on the optical image. An intense fluorescence signal was observed using the blue filter between 327 and $353 \mathrm{~nm}$ (black arrows) in Rivularia-rich laminations (underlined by dot lines in B,C) while the rest of the matrix is marked by a mixed fluorescence collected using the green and red filters. (C) The fluorescence emission signal associated with Rivularia-rich laminations was recorded and showed two bands at 316 and $341 \mathrm{~cm}^{-1}$. The fluorescence ranges covered by the three filters are indicated with respective colors and the precise localization where the spectrum was collected is given by a black star on the associated full-field RGB fluorescence image. 

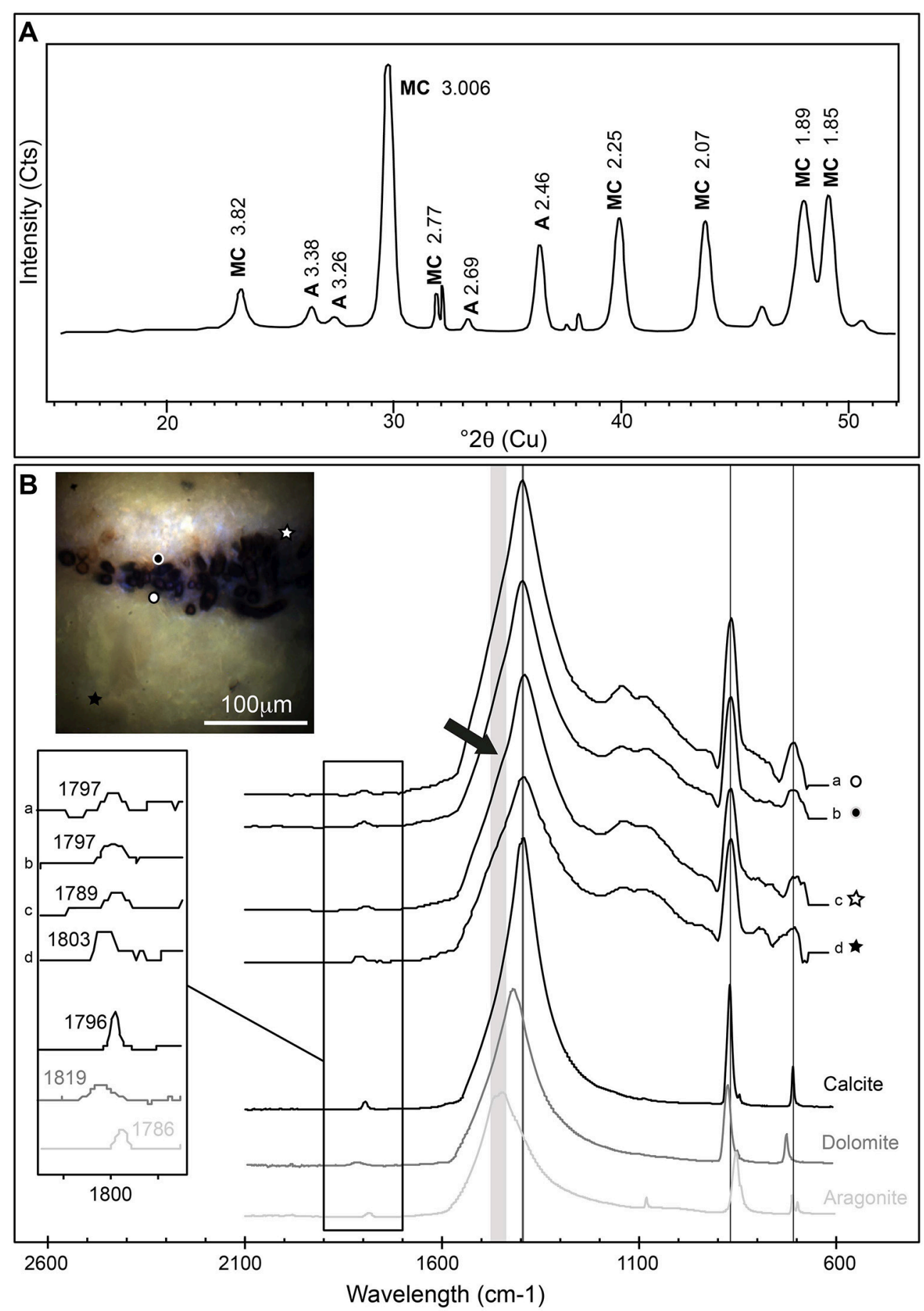

FIGURE 10 | (A) X-ray powder diffractogram obtained on a Rivularia-rich lamination. It shows Mg-rich calcite (MC) and aragonite (A) (Cts stands for counts). (B) ATR-FTIR spectra obtained on a Rivularia-rich lamination from a cross section of an oncoid associated with a black pustular mat also analyzed by S-DUV

(Figure 9B). The precise localization of the spectra is given in the associated full-field RGB fluorescence emission image (white and black circles and stars). ATR-FTIR spectra were compared to standard spectra of calcite, aragonite and dolomite (Rruff database; http://rruff.info/) and showed the predominance of calcite mixed with either a Mg-carbonate or aragonite, detected by the shift of the $\mathrm{CO}_{3}{ }^{2-}$ vibration bands at $1,796 \mathrm{~cm}^{-1}$ and a shoulder on the $\mathrm{CO}_{3}{ }^{2-}$ asymmetric stretching band around 1,400 $\mathrm{cm}^{-1}$ (black arrow). 
in these areas compared to other laminations. This could partly explain the different fluorescence pattern of this lamination. In that case, the presence of aragonite-rich laminations relatively to calcite-rich laminations may be a clue of biological activity (Lepot et al., 2008). Besides, the presence in the deep UV fluorescence emission spectrum extracted from this lamination (Figure 9C) of typical peaks associated with biological organic remnants at 316 and $341 \mathrm{~cm}^{-1}$ (Jamme et al., 2013) seemed to confirm the biological influence on these laminations. On the contrary, the absence of these signals in the other laminations may indicate that micritic and botryoidal laminations were either of pure chemical origin or did not preserve biological organic remnants if they were initially present. In the latter case, we may postulate that the presence of Rivularia sheaths, which favor the development of a large microbial consortium and are quite resistant to degradation, may have induced the preservation of a larger amount of biological organic remnants during mineralization comparatively to other laminations. It has important consequences for the search for biological traces in the fossil record. Indeed, these results are consistent with Lepot et al. (2008) who assumed a biological origin for stromatolites from the 2,724-Myr-old Tumbiana formation (Australia) based on the association of aragonite nanocrystals with organic globules in these formations. Specific laminations such as the ones rich in Rivularia-like structures presenting both higher aragonite together with a high organic content should then be tracked in order to decipher the biological origin of some laminations in fossil stromatolites.

\section{CONCLUSION}

By combining microscopic observations jointly with phylogenetic analyses, this study provides potential pathways for carbonate precipitation in the black pustular mat at Laguna Negra. Mineralization does not initiate directly on the Rivularia sheath or in the Rivularia sheath-cell interspace. This could be respectively related to the activity of epiphytic bacteria and to the capacity of Rivularia to locally change calcium concentrations by shedding a possible mineralized S-layer or by maintaining a positive surface potential to avoid $\mathrm{Ca}^{2+}$ adsorption. However, Rivularia play a critical role in favoring and structuring the development of a large microbial consortium excreting a well-developed EPS matrix. Carbonate precipitation then occurred via organo-mineralization processes, the EPS matrix serving as a template for mineral nucleation. In addition to the alkalinizing activity of Rivularia and diatoms, the presence of putative AAnPB of the Roseobacter clade suggests that ureolysis and denitrification can be important metabolisms triggering carbonate precipitation by favoring local alkalinization. With progressive precipitation, Rivularia get entombed with intact sheath and photosynthetic pigments. The microspectroscopic analyses of the corresponding laminations rich in Rivularia-sheaths structures in stromatolites indicate that a close combination of aragonite and a high organic content should then be considered as potential evidence of microbiallymediated processes of formation of stromatolites, providing biosignatures to be searched for in the fossil record.

\section{AUTHOR CONTRIBUTIONS}

EG, EM, and CP were responsible for the design of the study. EG, EM, CP, BM, LL, and FG performed experimental procedures and collected data. EG, KB, FG, and EM conducted FIB section, SEM and TEM. EG, EM, and LL performed DNA extraction and PCR. CP and EG performed FTIR analyses; CP, EG, BM, EM, FJ, and MR performed synchrotron-based Deep UV imaging experiment. ES performed XRD analyses. EM, CP, and EG interpreted the findings and drafted the manuscript. All authors critically reviewed content and approved the final version for publication.

\section{FUNDING}

This work was supported by grants from SECYT-UNC 20142016 project, International cooperation program CONICETCNRS Coopinter n²52891 RD2910 (2014-2016), Programme de coopération CONICET/Université Paris Diderot (2013-2014), CNRS/CONICET Bernardo Houssay Fellow (2016), EMBO short-term fellow (number 6682), and the French INSU 2015INTERRVIE program (PI: EG).

\section{ACKNOWLEDGMENTS}

The authors would like to thank M. Bisbal, P. Gil, G. Fernandez, and G. Paglini for their help with laboratory facilities in Argentina (IMMF-CONICET, INVIV-UNC). We also thank C. Mas for helping with confocal microscopy in Cordoba (CIQUIBICUNC), A. Mors for his help during field trips. We also thank O. Boudouma for assistance during SEM experiments at the Service Commun de Microscopie Electronique à Balayage (UPMC, Paris, France) and J. Cohen for laser microdissection experiments. Permission for sample collection was granted by the Ministerio de Ambiente y Desarrollo Sustentable, Catamarca, Argentina (number 18-10-2013, DPGA161 and 26-02-2015, DPGA:011 respectively). Part of this work was supported by the IPGP multidisciplinary program PARI and by Région Ile-de-France SESAME Grant No. 12015908. We acknowledge SOLEIL for provision of synchrotron beamtime (proposal $n^{\circ} 20150267$ ). This is IPGP contribution $n^{\circ} 3940$.

\section{SUPPLEMENTARY MATERIAL}

The Supplementary Material for this article can be found online at: https://www.frontiersin.org/articles/10.3389/fmicb. 2018.00996/full\#supplementary-material 


\section{REFERENCES}

Allwood, A. C., Walter, M. R., Kamber, B. S., Marshall, C. P., and Burch, I. W. (2006). Stromatolite reef from the early Archaean era of Australia. Nature 441, 714-718. doi: 10.1038/nature04764

Aloisi, G., Gloter, A., Kruger, M., Wallmann, K., Guyot, F., and Zuddas, P. (2006). Nucleation of calcium carbonate on bacterial nanoglobules. Geology 34 , 1017-1020. doi: 10.1130/G22986A.1

Altermann, W., Kazmierczak, J., Oren, A., and Wright, T. (2006). Cyanobacterial calcification and its rock-building potential during 3.5 billion years of Earth history. Geobiology 4, 147-166. doi: 10.1111/j.1472-4669.2006.00076.x

Altschul, S. F., Madden, T. L., Schäffer, A. A., Zhang, J., Zhang, Z., Miller, W., et al. (1997). Gapped BLAST and PSI-BLAST: a new generation of protein database search programs. Nucleic Acids Res. 25, 3389-3402. doi: 10.1093/nar/25.17.3389

Arp, G., Reimer, A., and Reitner, J. (2001). Photosynthesis-induced biofilm calcification and calcium concentrations in Phanerozoic oceans. Science 292, 1701-1704. doi: 10.1126/science.1057204

Awramik, S. M., and Sprinkle, J. (1999). Proterozoic stromatolites: the first marine evolutionary biota. Hist. Biol. 13, 241-253. doi: 10.1080/08912969909386584

Bapteste, E., Brochier, C., and Boucher, Y. (2005). Higher-level classification of the Archaea: evolution of methanogenesis and methanogens. Archaea 1, 353-363. doi: 10.1155/2005/859728

Barbieri, R., Cavalazzi, B., Stivaletta, N., and López-García, P. (2014). Silicified biota in high-altitude, geothermally influenced ignimbrites at El Tatio geyser field, Andean Cordillera (Chile). Geomicrobiology J. 31, 493-508. doi: 10.1080/01490451.2013.836691

Benzerara, K., Menguy, N., López-Garcia, P., Yoon, T.-H., Kazmierczak, J., Tyliszczak, T., et al. (2006). Nanoscale detection of organic signatures in carbonate microbialites. Proc. Natl. Acad. Sci. U.S.A. 103, 9440-9445. doi: $10.1073 /$ pnas. 0603255103

Berelson, W. M., Corsetti, F. A., Pepe-Ranney, C., Hammond, D. E., Beaumont, W., and Spear, J. R. (2011). Hot spring siliceous stromatolites from Yellowstone National Park: assessing growth rate and laminae formation. Geobiology 9, 411-424. doi: 10.1111/j.1472-4669.2011.00288.x

Bosak, T., Greene, S., and Newman, D. K. (2007). A likely role for anoxygenic photosynthetic microbes in the formation of ancient stromatolites. Geobiology 5, 119-126. doi: 10.1111/j.1472-4669.2007.00104.x

Bosence, D., Gibbons, K., Le Heron, D. P., Morgan, W. A., Pritchard, T., and Vining, B. A. (2015). "Microbial carbonates in space and time: introduction" in Microbial Carbonates in Space and Time: Implications for Global Exploration and Production, Vol. 418, eds D. W. J. Bosence, K. Gibbons, D. P. Le Heron, T. Pritchard and B. A. Vining (London: Geological Society, Special Publications), 1-15.

Braissant, O., Cailleau, G., Dupraz, C., and Verrecchia, A. P. (2003). Bacterially induced mineralization of calcium carbonate in terrestrial environments: the role of exopolysaccharides and amino acids. J. Sediment. Res. 73, 485-490. doi: 10.1306/111302730485

Braissant, O., Decho, A., Dupraz, C., Glunk, C., Przekop, K., and Visscher, P. (2007). Exopolymeric substances of sulfate-reducing bacteria: interactions with calcium at alkaline $\mathrm{pH}$ and implication for formation of carbonate minerals. Geobiology 5, 401-411. doi: 10.1111/j.1472-4669.2007.00117.x

Brocks, J. J., and Pearson, A. (2005). Building the tree of life. Rev. Mineral. Geochem. 59, 233-258. doi: 10.2138/rmg.2005.59.10

Buick, R., Dunlop, J. S. R., and Groves, D. I. (1981). Stromatolite recognition in ancient rocks: an appraisal of irregularly laminated structures in an Early Archaean chert-barite unit from North Pole, Western Australia. Alcheringa 5, 161-181. doi: 10.1080/03115518108566999

Burne, R., and Moore, L. (1987). Microbialites: organosedimentary deposits of benthic microbial communities. Palaios 2, 241-254. doi: 10.2307/3514674

Chagas, A. A. P., Webb, G. E., Burne, R. V., and Southam, G. (2016). Modern lacustrine microbialites: towards a synthesis of aqueous and carbonate geochemistry and mineralogy. Earth Sci. Rev. 162, 338-363. doi: 10.1016/J.EARSCIREV.2016.09.012

Couradeau, E., Benzerara, K., Gérard, E., Moreira, D., Tavera, R., and Lopez Garcia, P. (2014). In situ microscale cyanobacterial calcification in modern microbialites. Biogeosciences 10, 5255-5266. doi: 10.5194/bg-10-5255-2013

Defarge, C., Gautret, P., Reitner, J., and Trichet, J. (2009). Defining organominerals: comment on 'defining biominerals and organominerals: direct and indirect indicators of life'. Sediment. Geol. 213, 152-155. doi: 10.1016/j.sedgeo.2008.04.002

Diehl, H., and Ellingboe, J. L. (1956). Indicator for titration of calcium in presence of magnesium using disodium dihydrogen ethylenediamine tetraacetate. Anal. Chem. 28, 882-884. doi: 10.1021/ac60113a030

Doi, M., and Shioi, Y. (1991). Enhancement of denitrifying activity in cells of Roseobacter denitrificans grown aerobically in the light. Plant Cell Physiol. 32, 365-370. doi: 10.1093/oxfordjournals.pcp.a078089

Douglas, S., and Beveridge, T. J. (1998). Mineral formation by bacteria in natural microbial communities. FEMS Microbiol. Ecol. 26, 79-88. doi: 10.1111/j.1574-6941.1998.tb00494.x

Dupraz, C., Reid, R. P., Braissant, O., Decho, A. W., Norman, R. S., and Visscher, P. T. (2009). Processes of carbonate precipitation in modern microbial mats. Earth Sci. Rev. 96, 141-152. doi: 10.1016/j.earscirev.2008.10.005

Dupraz, C., and Visscher, P. T. (2005). Microbial lithification in marine stromatolites and hypersaline mats. Trends Microbiol. 13, 429-438. doi: 10.1016/j.tim.2005.07.008

Engel, A. S., Johnson, L. R., and Porter, M. L. (2013). Arsenite oxidase gene diversity among Chloroflexi and Proteobacteria from El Tatio geyser Field, Chile. FEMS Microbiol. Ecol. 83, 745-756. doi: 10.1111/1574-6941.12030

Erşan, Y. C., de Belie, N., and Boon, N. (2015). Microbially induced $\mathrm{CaCO}_{3}$ precipitation through denitrification: an optimization study in minimal nutrient environment. Biochem. Engineer. J. 101, 108-118. doi: 10.1016/j.bej.2015.05.006

Farías, M. E., Contreras, M., Rasuk, M. C., Kurth, D., Flores, M. R., Poire, D. G., et al. (2014). Characterization of bacterial diversity associated with microbial mats, gypsum evaporites and carbonate microbialites in thalassic wetlands: Tebenquiche and La Brava, Salar de Atacama, Chile. Extremophiles 18, 311-329. doi: 10.1007/s00792-013-0617-6

Farías, M. E., Rascovan, N., and Toneatti, D. M. (2013). The discovery of stromatolites developing at $3570 \mathrm{~m}$ above sea level in a high-altitude volcanic lake Socompa, Argentinean Andes. PLoS ONE 8:e53497. doi: 10.1371/journal.pone.0053497

Fernandez, A., Rasuk, M. C., Visscher, P., Contreras, M., Novoa, F., Poire, D., et al. (2015). Microbial diversity in sediment ecosystems (evaporites domes, microbial mats and crusts) of hypersaline Laguna Tebenquiche, Salar de Atacama, Chile. Front. Microbiol. 7:1284. doi: 10.3389/fmicb.2016.01284

Fogg, G. (1983). The ecological significance of extracellular products of phytoplankton photosynthesis. Bot. Mar. 26, 3-14. doi: 10.1515/botm. 1983.26.1.3

Foster, J. S., Green, S. J., Ahrendt, S. R., Golubic, S., Reid, P. R., Hetherington, K. L., et al. (2009). Molecular and morphological characterization of cyanobacterial diversity in the stromatolites of Highborne Cay, Bahamas. ISME J. 3, 573-587. doi: 10.1038/ismej.2008.129

Garcial-Pichel, F., and Castenholz, W. (1991). Characterization and biological implications of sytonemin a cyanobacterial sheath pigment. J. Phycol. 27, 395-409. doi: 10.1111/j.0022-3646.1991.00395.x

Gérard, E., Ménez, B., Couradeau, E., Moreira, D., Benzerara, K., Tavera, R., et al. (2013). Specific carbonate-microbe interactions in the modern microbialites of Lake Alchichica (Mexico). ISME J. 7, 1997-2009. doi: 10.1038/ismej. 2013.81

Giuliani, A., Jamme, F., Rouam, V., Wien, F., Giorgetta, J. L., Lagarde, B., et al. (2009). DISCO: a low-energy multipurpose beamline at synchrotron SOLEIL. J. Synchrotron Radiat. 16, 835-841. doi: 10.1107/S0909049509034049

Glunk, C., Dupraz, C., Braissant, O., Gallagher, K. L., Verrecchia, E. P., and Visscher, P. T. (2011). Microbially-mediated carbonate precipitation in a hypersaline lake, Big Pond (Eleuthera, Bahamas). Sedimentology 58, 720-736. doi: 10.1111/j.1365-3091.2010.01180.x

Gomez, F., Kah, L., Bartley, K., and Astini, R. (2014). Microbialites in a highaltitude Andean lake: multiple controls on carbonate precipitation and lamina accretion. Palaios 29, 233-249. doi: 10.2110/palo.2013.049

Gomez, F. J., Llewski, C., Boidi, F. J., Farias, M. E., and Gérard, E. (2018). Calcium carbonate precipitation in diatom-rich microbial mats: the Laguna Negra hypersaline lake, Catamarca, Argentina. J. Sediment. Res. 88.

González-Muñoz, M. T., Rodriguez-Navarro, C., Martínez-Ruiz, F., Arias, J. M., Merroun, M. L., and Rodriguez-Gallego, M. (2010). "Bacterial biomineralization: new insights from Myxococcus-induced mineral precipitation," in Tufas and Speleothems: Unravelling the Microbial and 
Physical Controls, Vol. 336, eds H. M. Pedley and M. Rogerson (London: Geological Society; Special Publications), 31-50.

Grossart, H.-P., Levold, F., Allgaier, M., Simon, M., and Brinkhoff, T. (2005). Marine diatom species harbour distinct bacterial communities. Environ. Microbiol. 7, 860-873. doi: 10.1111/j.1462-2920.2005. 00759.x

Grotzinger, J. P., and Knoll, A. H. (1999). Stromatolites in Precambrian carbonates: evolutionary mileposts or environmental dipsticks? Annu. Rev. Earth Planet. Sci. 27, 313-358. doi: 10.1146/annurev.earth.27.1.313

Guiry, M. D., and Morrison, L. (2015). "Internet information resources for marine algae," in Marine Algae Biodiversity, Taxonomy, Environmental Assessment, and Biotechnology, eds L. Pereira and J. L Neto (Boca Raton, FL: CRC Press, Taylor \& Francis), 357-376.

Heaney, P., Vicenzi, E., Giannuzzi, L., and Livi, K. (2001). Focused ion beam milling: a method of site-specific sample extraction for microanalysis of Earth and planetary materials. Am. Mineral. 86, 1094-1099. doi: 10.2138/am-2001-8-917

Hirose, S., Nagashima, K. V. P., Matsuura, K., and Haruta, S. (2012). Diversity of purple phototrophic bacteria, inferred from pufM gene, within epilithic biofilm in Tama River, Japan. Microbes Environ. 27, 327-329. doi: 10.1264/jsme2.ME11306

Howarth, R., Richard, F., Seviur, E., Seviou, R., Blackall, L., Pickup, R., et al. (1999). Phylogenetic relationships of filamentous sulfur bacteria (Thiothrix spp. and Eikelboom type $021 \mathrm{~N}$ bacteria) isolated from waste water treatment plants and description of Thiothrix eikelboomii sp. nov., Thiothrix unzii sp. nov., Thiothrix fructosivorans sp. nov. and Thiothrix defluvii sp. nov. Int. J. Syst. Evol. Microbiol. 49, 1817-1827. doi: 10.1099/00207713-49-4-1817

Imachi, H., Sakai, S., Sekiguchi, Y., Hanada, S., Kamagata, Y., Ohashi, A., et al. (2008). Methanolinea tarda gen. nov., sp. nov., a methane-producing archaeon isolated from a methanogenic digester sludge. Int. J. Syst. Evol. Microbiol. 58, 294-301. doi: 10.1099/ijs.0.65394-0

Jamme, F., Kascakova, S., Villette, S., Allouche, F., Pallu, S., Rouam, V., et al. (2013). Deep UV autofluorescence microscopy for cell biology and tissue histology. Biol. Cell. 105, 277-288. doi: 10.1111/boc.201200075

Jamme, F., Villette, S., Giuliani, A., Rouam, V., Wien, F., Lagarde, B., et al. (2010). Synchrotron UV fluorescence microscopy uncovers new probes in cells and tissues. Microsc. Microanal. 16, 507-514. doi: 10.1017/S14319276100 93852

Jimenez-López, C., Jroundi, F., Rodriguez-Gallego, M., Arias, J. M., and GonzálezMuñoz, M. T. (2007). "Biomineralization induced by Myxobacteria" in Communicating Current Research and Educational Topics and Trends in Applied Microbiology, Vol. 1, ed A. Méndez-Vilas (Badajoz: Formatex), $143-154$.

Jukes, T. H., and Cantor, C. R. (1969). "Evolution of protein molecules," in Mammalian Protein Metabolism III, ed H. N. Munro (New York, NY: Academic Press), 21-132.

Kang, C.-H., Han, S.-H., Shin, Y., Oh, S. J., and So, J.-S. (2014). Bioremediation of Cd by microbially induced calcite precipitation. Appl. Biochem. Biotechnol. 172, 2907-2915. doi: 10.1007/s12010-014-0737-1

Kazmierczak, J., Fenchel, T., Kühl, M., Kempe, S., Kremer, B., Łacka, B., et al. (2015). $\mathrm{CaCO}_{3}$ precipitation in multilayered cyanobacterial mats: clues to explain the alternation of micrite and sparite layers in calcareous stromatolites. Life 5, 744-769. doi: 10.3390/life5010744

Kempe, S., Kazmierczak, J., Landmann, G., Konuk, T., Reimer, A., and Lipp, A. (1991). Largest known microbialites discovered in Lake Van, Turkey. Nature 349, 605-608. doi: 10.1038/349605a0

Kenward, P. A., Goldstein, R. H., Gonzalez, L. A., and Roberts, J. A. (2009). Precipitation of low-temperature dolomite from an anaerobic microbial consortium: the role of methanogenic Archaea. Geobiology 7 , 556-565. doi: 10.1111/j.1472-4669.2009.00210.x

Khan, S. T., Nakagawa, Y., and Harayama, S. (2007). Sediminibacter furfurosus gen. nov., sp. nov. and Gilvibacter sediminis gen. nov., sp. nov., novel members of the family Flavobacteriaceae. Int. J. Syst. Evol. Microbiol. 57, 265-269. doi: 10.1099/ijs.0.64628-0

Knoll, A. H. (2003). Biomineralization and evolutionary history. Rev. Mineral. Geochem. 54, 329-356. doi: 10.2113/0540329

Koblizek, M. (2015). Ecology of aerobic anoxygenic phototrophs in aquatic environments. FEMS Microbiol. Rev. 39, 854-870. doi: 10.1093/femsre/fuv032
Kwak, M. J., Lee, J. S., Lee, K. C., Kim, K. K., Eom, M. K., Kim, B. K., et al. (2014). Sulfitobacter geojensis sp. nov., Sulfitobacter noctilucae sp. nov., and Sulfitobacter noctilucicola sp. nov., isolated from coastal seawater. Int. J. Syst. Evol. Microbiol. 64, 3760-3767. doi: 10.1099/ijs.0.065961-0

Leavitt, P. R., Vinebrooke, R. D., Donald, D. B., Smol, J. P., and Schindler, D. W. (1997). Past ultraviolet radiation environments in lakes derived from fossil pigments. Nature 388, 457-459. doi: 10.1038/41296

Lenk, S., Moraru, C., Hahnke, S., Arnds, J., Richter, M., Kube, M., et al. (2012). Roseobacter clade bacteria are abundant in coastal sediments and encode a novel combination of sulfur oxidation genes. ISME J. 6, 2178-2187. doi: 10.1038/ismej.2012.66

Lepot, K., Benzerara, K., Brown, G. E. Jr., and Philippot, P. (2008). Microbially influenced formation of 2,724-million-year-old stromatolites. Nat. Geosci. 1, 118-121. doi: 10.1038/ngeo107

Logan, B. W. (1961). Cryptozoon and associated stromatolites from the recent, Shark Bay, Western Australia. J. Geol. 69, 517-533.

Lucena, T., Ruvira, M. A., Macián, M. C., Pujalte, M. J., and Arahal, D. R. (2013). Description of Tropicibacter mediterraneus sp. nov. and Tropicibacter litoreus sp. nov. Syst. Appl. Microbiol. 36, 325-329. doi: 10.1016/j.syapm.2013.04.001

Ludwig, W., Strunk, O., Westram, R., Richter, L., Meier, H., Yadhukumar, Buchner, A., et al. (2004). ARB: a software environment for sequence data. Nucleic Acids Res. 32, 1363-1371. doi: 10.1093/nar/gkh293

Luo, H., and Moran, M. A. (2014). Evolutionary ecology of the marine Roseobacter clade. Microbiol. Mol. Biol. Rev. 78 , 573-587. doi: 10.1128/MMBR.00020-14.

Ma, K., Liu, X., and Dong, X. (2006). Methanosaeta harundinacea sp. nov., a novel acetate-scavenging methanogen isolated from a UASB reactor. Int. J. Syst. Evol. Micr. 56, 127-131. doi: 10.1099/ijs.0.63887-0

Maidana, N. I., and Seeligmann, C. (2006). Diatomeas (Bacillariophyceae) de ambientes acuáticos de altura de la Provincia de Catamarca, Argentina II. Bol. Soc. Argent. Bot. 41, 1-13.

Martinez, R. E., Gardés, E., Pokrovsky, O. S., Schott, J., and Oelkers, E. H. (2010). Do photosynthetic bacteria have a protective mechanism against carbonate precipitation at their surfaces? Geochim. Cosmochim. Acta 74, 1329-1337. doi: 10.1016/j.gca.2009.11.025

Martinez, R. E., Pokrovsky, O. S., Schott, J., and Oelkers, E. H. (2008). Surface charge and zeta potential of metabolically active and dead cyanobacteria. $J$. Colloid Interface Sci. 323, 317-325. doi: 10.1016/j.jcis.2008.04.041

Meister, P. (2013). Two opposing effects of sulfate reduction on calcite and dolomite precipitation in marine, hypersaline and alkaline environments. Geology 41, 499-502. doi: 10.1130/G34185.1

Merz, M. U. E. (1992). The biology of carbonate precipitation by cyanobacteria. Facies 26, 81-102. doi: 10.1007/BF02536920

Merz-Prei, M., and Riding, R. (1999). Cyanobacterial tufa calcification in two freshwater streams: Ambient environment, chemical thresholds and biological processes. Sediment. Geol. 126, 103-124. doi: 10.1007/BF02539795

Michaelis, W., Seifert, R., Nauhaus, K., Treude, T., Thiel, V., Blumenberg, M., et al. (2002). Microbial reefs in the Black sea fueled by anaerobic oxidation of methane. Science 297, 1014-1015. doi: 10.1126/science.1072502

Nedashkovskaya, O., Kim, S., Kyun Han, S., Lysenko, A. M., Rohde, M., Rhee, M. S., et al. (2004). Maribacter gen. nov., a new member of the family Flavobacteriaceae, isolated from marine habitats, containing the species Maribacter sedimenticola sp. nov., Maribacter aquivivus sp. nov., Maribacter orientalis sp. nov. and Maribacter ulvicola sp. nov. Int. J. Syst. Evol. Microbiol. 54, 1017-1023. doi: 10.1099/ijs.0.02849-0

Nedashkovskaya, O., Vancanney, T., Seung, B., and Zhukova, N. (2009). Winogradskyella echinorum sp. nov., a marine bacterium of the family Flavobacteriaceae isolated from the sea urchin Strongylocentrotus intermedius. Int. J. Syst. Evol. Microbiol. 59, 1465-1468. doi: 10.1099/ijs.0.005421-0

Nutman, A. P., Bennett, V. C., Friend, C. R. L., Van Kranendonk, M. J., and Chivas, A. R. (2016). Rapid emergence of life shown by discovery of 3,700-millionyear-old microbial structures. Nature 537, 535-538. doi: 10.1038/nature 19355

Orphan, V. J., Jahnke, L. L., Embaye, T., Turk, K. A., Pernthaler, A., Summons, R. E., et al. (2008). Characterization and spatial distribution of methanogens and methanogenic biosignatures in hypersaline microbial mats of Baja California. Geobiology 6, 376-393. doi: 10.1111/j.1472-4669.2008.00166.x

Overmann, J., and van Gemerden, H. (2000). Microbial interactions involving sulfur bacteria: implications for the ecology and evolution 
of bacterial communities. FEMS Microbiol. Rev. 24, 591-599. doi: 10.1111/j.1574-6976.2000.tb00560.x

Oz, A., Sabehi, G., Koblízek, M., Massana, R., and Béjà, O. (2005). Roseobacterlike bacteria in Red and Mediterranean Sea aerobic anoxygenic photosynthetic populations. Appl. Environ. Microbiol. 71, 344-353. doi: 10.1128/AEM.71.1.344

Pagani, I., Chertkov, O., Lapidus, A., Lucas, S., Del Rio, T. G., Tice, H., et al. (2011). Complete genome sequence of Marivirga tractuosa type strain (H-43). Stand. Genomic Sci. 4, 154-162. doi: 10.4056/sigs. 1623941

Pentecost, A., and Ulrich, F. (2010). Photosynthesis and calcification of the stromatolitic freshwater cyanobacterium Rivularia. Eur. J. Phycol. 45, 345-353. doi: 10.1080/09670262.2010.492914

Perry, R. S., McLoughlin, N., Lynne, B. Y., Sephton, M. A., Oliver, J. D., Perry, C. C., et al. (2007). Defining biominerals and organominerals: direct and indirect indicators of life. Sed. Geol. 201, 157-179. doi: 10.1016/j.sedgeo.2007.05.014

Phoenix, V., Martinez, R., Konhauser, K., and Ferris, F. (2002). Characterization and implications of the cell surface reactivity of Calothrix sp. strain KC97. Appl. Environ. Microbiol. 68, 4827-4834. doi: 10.1128/AEM.68.10.4827-4834.2002

Phoenix, V. R., Adams, D. G., and Konhauser, K. O. (2000). Cyanobacterial viability during hydrothermal biomineralisation. Chem. Geol. 169, 329-338. doi: 10.1016/S0009-2541(00)00212-6

Pruesse, E., Peplies, J., and Glöckner, F. O. (2012). SINA: accurate high-throughput multiple sequence alignment of ribosomal RNA genes. Bioinformatics 28, 1823-1829. doi: 10.1093/bioinformatics/bts252.

Quast, C., Pruesse, E., Yilmaz, P., Gerken, J., Schweer, T., Yarza, P., et al. (2013). The SILVA ribosomal RNA gene database project: improved data processing and web-based tools. Nucleic Acids Res. 41, D590-D596. doi: 10.1093/nar/gks1219

Reitner, J., Paul, J., Arp, G., and Hause-Reitner, D. (1996). "Lake Thetis domal microbialites. A complex framework of calcified biofilms and organomicrites (Cervantes, Western Australia)," in Global and Regional Controls on Biogenic Sedimentation. I. Reef Evolution Research Reports, Vol. SB2, eds J. Reitner, F. Neuweiler, and F. Gunkel (Göttingen: Göttinger Arb. Geol. Paläont, Sonderband), 85-89.

Riding, R. (1977). "Skeletal stromatolites" in Fossil Algae-Recent Results and Developments, ed E. Flügel (Berlin; Germany: Springer), 57-60.

Riding, R. (2006). Cyanobacterial calcification, carbon dioxide concentrating mechanisms, and Proterozoic-Cambrian changes in atmospheric composition. Geobiology 4, 299-316. doi: 10.1111/j.1472-4669.2006.00087.x

Roberts, J. A., Bennet, P. C., Gonzalez, L. A., Macpherson, G. L., , and Milliken, K. L. (2004). Microbial precipitation of dolomite in methanogenic groundwater. Geology 32, 277-280, doi: 10.1130/G20246.1.

Romesser, J. A., Wolfe, R. S., Mayer, F., Spiess, E., and Walther-Mauruschat, A. (1979). Methanogenium, a new genus of marine methanogenic bacteria, and characterization of Methanogenium cariaci sp. nov. and Methanogenium marisnigri sp. nov. Arch. Microbiol. 121, 147-153. doi: 10.1007/BF00689979

Saghaï, A., Zivanovic, Y., Zeyen, N., Moreira, D., Benzerara, K., Deschamps, P., et al. (2015). Metagenome-based diversity analyses suggest a significant contribution of non-cyanobacterial lineages to carbonate precipitation in modern microbialites. Front. Microbiol. 6:797. doi: 10.3389/fmicb.2015.00797

Schink, B. (2002). Synergistic interactions in the microbial world. Antonie Van Leeuwenhoek 81, 257-261. doi: 10.1023/A:1020579004534

Schneider, C. S., Rasband, W. S., and Eliceiri, W. (2012). NIH Image to ImageJ: 25 years of image analysis. Nat. Methods 9, 671-675. doi: 10.1038/nmeth.2089

Scholten, J. C. M., Joye, S. B., Hollibaugh, J. T., and Murrell, J. C. (2005). Molecular analysis of the sulfate reducing and archaeal community in a meromictic soda lake (Mono Lake, California) by targeting $16 \mathrm{~S}$ rRNA, mcrA, apsA, and $d s r A B$ genes. Microbial. Ecol. 50, 29-39. doi: 10.1007/s00248-004-0085-8
Singh, S., and Mishra, A. (2014). Regulation of calcium ion and its effect on growth and developmental behavior in wild type and $n t c A$ mutant of Anabaena sp. PCC 7120 under varied levels of $\mathrm{CaCl}_{2}$. Microbiology 83, 235-246. doi: $10.1134 /$ S002626171403014X

Smith, R. J., and Wilkins, A. (1988). A correlation between intracellular calcium and incident irradiance in Nostoc 6720. New Phytol. 109, 157-161. doi: 10.1111/j.1469-8137.1988.tb03703.x

Stamatakis, A., Hoover, P., and Rougemont, J. (2008). A rapid bootstrap algorithm for the raxml web servers. Syst. Biol. 57, 758-771. doi: $10.1080 / 10635150802429642$

Tamura, K., Stecher, G., Peterson, D., Filipski, A., and Kumar, S. (2013). MEGA6: Molecular Evolutionary Genetics Analysis Version 6.0. Mol. Biol. Evol. 30, 2725-2729. doi: 10.1093/molbev/mst197

Thompson, J. B., Schultz-Lam, S., Beveridge, T. J., and Des Marais, D. J. (1997). Whiting events: biogenic origin due to the photosynthetic activity of cyanobacterial picoplankton. Limnol. Oceanogr. 42, 133-141. doi: 10.4319/lo.1997.42.1.0133

Thoury, M., Echard, J.-P., Réfrégiers, M., Berrie, B., Nevin, A., Jamme, F., et al. (2011). Synchrotron UV-visible multispectral luminescence micro imaging of historical samples. Anal. Chem. 83, 1737-1745. doi: 10.1021/ac102986h

Walter, M. R., Bauld, J., and Brock, T. D. (1972). Siliceous algal and bacterial stromatolites in hot spring and geyser effluents of Yellowstone national park. Science 178, 402-405. doi: 10.1126/science.178.4059.402

Yilmaz, P., Parfray, L. W., Yarza, P., Gerken, J., Pruesse, E., Quast, C., et al. (2014). The SILVA and "All-species Living Tree Project (LTP)" taxonomic frameworks. Nucleic Acids Res. 42, D643-D648. doi: 10.1093/nar/ gkt1209.

Yoon, J., Matsuo, Y., Katsuta, A., Jang, J. H., Matsuda, S., Adachi, K., et al. (2008). Haloferula rosea gen. nov., sp. nov., Haloferula harenae sp. nov., Haloferula phyci sp. nov., Haloferula helveola sp. nov. and Haloferula sargassicola sp. nov., five marine representatives of the family Verrucomicrobiaceae within the phylum 'Verrucomicrobia'. Int. J. Syst. Evol. Microbiol. 58, 2491-2500. doi: 10.1099/ijs.0.2008/000711-0

Zhang, Y., Sun, Y., Jiao, N., Stepanauskas, R., and Luo, H. (2016). Ecological genomics of the uncultivated marine Roseobacter lineage CHAB-I-5. Appl. Environ. Microbiol. 82, 2100-2111. doi: 10.1128/AEM. 03678-15

Zhu, T., and Dittrich, M. (2016). Carbonate precipitation through microbial activities in natural environment, and their potential in biotechnology: a review. Front. Bioeng. Biotechnol. 4:4. doi: 10.3389/fbioe.2016.00004

Zippel, B., and Neu, T. R. (2011). Characterization of glycoconjugates of extracellular polymeric substances in tufa-associated biofilms by using fluorescence lectin-binding analysis. Appl. Environ. Microbiol. 77, 505-516. doi: 10.1128/AEM.01660-10

Conflict of Interest Statement: The authors declare that the research was conducted in the absence of any commercial or financial relationships that could be construed as a potential conflict of interest.

Copyright $\odot 2018$ Mlewski, Pisapia, Gomez, Lecourt, Soto Rueda, Benzerara, Ménez, Borensztajn, Jamme, Réfrégiers and Gérard. This is an open-access article distributed under the terms of the Creative Commons Attribution License (CC BY). The use, distribution or reproduction in other forums is permitted, provided the original author(s) and the copyright owner are credited and that the original publication in this journal is cited, in accordance with accepted academic practice. No use, distribution or reproduction is permitted which does not comply with these terms. 